\title{
Catalonia independence claim: \\ An analysis from the standpoint of international law
}

\author{
Robert KOLB* ${ }^{*}$ Tarcisio GAZZINI **
}

\begin{abstract}
The article offers a systematic analysis of the independence claim of the Autonomous Community of Catalonia (hereinafter "Catalonia") from the standpoint of international law and includes a concise discussion of the key concepts of statehood, territorial integrity and recognition. It then examines the right of peoples to self-determination, which remains the crux of the matter, and defines its content in the colonial context and beyond it. It demonstrates that outside the colonial context and with the possible exception of remedial secession (which can be excluded in the case of Catalonia), there is no legal entitlement to secede. The right to self-determination must be implemented within the jurisdiction of Spain. It thus becomes essentially a matter of autonomy and powers distribution. It is within the current legal framework, based primarily on the Spanish Constitution and the Catalan Statute of Autonomy that the parties must hammer out a political solution, which must follow the road map designed by the Constitutional Court in a series of decisions rendered throughout the crisis. The Court has consistently upheld the unity and territorial integrity of Spain, the full enjoyment by Catalonia of all the powers contained in the Statute of Autonomy, and the right to Catalonia to project, within the constitutional and statutory limits, its activities at the international level. The article concludes that the current legal framework is sufficiently clear and flexible to accommodate the rights and responsibilities of the central government to preserve the unity of Spain as well as the legitimate ambitions of Catalonia to develop and pursue its policies in accordance with the Constitution and the Statute.
\end{abstract}

Keywords: Spain - Catalonia independence - Sovereignty - Self-determination

\section{(A) INTRODUCTION}

The attempt by the authorities of the Autonomous Community of Catalonia (hereinafter "Catalonia") to break away from Spain and create an independent State has dominated the political agenda in the country for almost a decade. It has provoked an unprecedented showdown between the Government and Catalan authorities, created a sharp divide at the national level and within the population of Catalonia, and triggered several important pronouncements by the Spanish Constitutional Court.

The purpose of this article is to provide a systematic assessment of the independence claim put forward by Catalonia from the standpoint of international law. Clarifying the respective rights and obligations of Spain and Catalonia under international law is indispensable for the purpose of conducting meaningful negotiations towards a satisfactory political solution of the crisis consistent with the Constitution.

The article first offers an overview of the events leading to the 2017 referendum and its consequences, focusing on the articulation by Catalan authorities of the independence claim through several legal and political documents, the reactions of the Spanish Government and the relevant decisions of the Spanish Constitutional Court. It then examines the key international law principles

aे Article received on 5 June 2021, accepted on 22 August 2021 and published on line on 31 January 2021.

* Professor of Public International Law, University of Geneva. Email: Robert.kolb@unige.ch.

** Professor of Public International Law, Università di Padova. Email: tarcisio.gazzini@unipd.it. 
and concepts without which it would be impossible to proficiently deal with the question of the Catalan independence claim. Particular attention will be paid to statehood, territorial integrity, recognition and, most importantly, the right of peoples to self-determination, which is considered a cornerstone of modern international law, despite its normative indeterminacy. It finally assesses the Catalan claim to independence and its implications. The analysis includes the so-called "right to decide", which is peculiar to the Catalan claim, and offers some indications on how Spain and Catalonia may eventually reach a mutually satisfactory agreement along the lines elucidated by the Constitutional Court.

\section{(B) OVERVIEW OF THE EVENTS RELATED TO THE CLAIM OF INDEPENDENCE}

The 1978 Constitution of Spain provides that "[n]ational sovereignty is vested in the Spanish people, from whom emanate the powers of the State" (Article 1.2). It also proclaims "the indissoluble unity of the Spanish nation, the common and indivisible country of all Spaniards" and guarantees "the right to autonomy of the nationalities and regions of which it is composed, and the solidarity amongst them all" (Article 2). Article 149 defines the exclusive competences of the State, while Article 97 specifically reserves to the Government inter alia the direction of foreign policy. Article 148 indicates the matters that may fall within the competences of Autonomous Communities. ${ }^{1}$

The right to autonomy of the nationalities and regions has been implemented through the adoption of several statutes of autonomy governing the relationship between the central government and the autonomous communities, as well as the distribution of the respective powers. Regarding Catalonia, the first Statute of autonomy was adopted in 1979. According to Article 1(1), Catalonia, as a nationality, was constituted as an Autonomous Community in order to achieve self-government, in accordance with the Constitution. ${ }^{2}$

In 2005, the Catalan Parliament adopted a draft for a new and more sophisticated Statute, which declared that Catalonia, as a nation, exercises self-government through its own institutions and is constituted as an Autonomous Community in accordance with the Constitution and the Statute itself. ${ }^{3}$ The final version of the Statute of autonomy, however, emphasised that Catalonia's self-government is founded on the Constitution and the historical rights of the Catalan people. ${ }^{4}$ It also proclaimed the wish of Catalonia "to develop its political personality within the framework of a State, which recognises and respects the diversity of identities of the peoples of Spain". It also reverted to Catalonia as a nationality (instead of a nation).

The Statute was then the object of a rather controversial decision by the Constitutional Court. ${ }^{5}$ This complex decision deals with many legal issues and declared unconstitutional several provisions of the Statute. Throughout the decision, the Court adamantly insisted that Catalonia autonomy was based on and must be exercised in accordance with the Constitution. In a key passage, it held that the Statutes of Autonomy are subordinated to the Constitution and that the provisions of the Statutes are not expression of a sovereign power, but merely of a devolved autonomy. It also distinguished

Spanish Constitution 1978, text here.

2 The Statute was adopted by the Parliamentary Assembly on 16 December 1978 and approved through a referendum held on 25 October 1979, text here.

3 Proposal approved by the Plenary Assembly of Parliament, 30 September 2005, BOPC 224, 3 October 2005.

4 Organic Act 6/2006, 19 July 2006, preamble.

5 STC 31/2010, 28 June 2010. 
"Spanish people", as the sole holder of national sovereignty at the origin of the Constitution, from "people of Catalonia", as the as the holder of the public powers to be exercised in conformity with the Constitution and the Statute of autonomy.

The decision, which was later described as causing "the partial revocation and complete denaturing" of the 2006 Statute of autonomy, ${ }^{6}$ ignited the firm reaction of the Catalonian Parliament. Two resolutions marked the rupture with the previous approach respectful of the Constitution. Resolution 742/IX, introduced the "right to decide" and announced Catalonia as "a new State of Europe" based on the imprescriptible and inalienable right to self-determination as democratic expression of its sovereignty as nation. ${ }^{7}$ The Catalan claim to independence was then reiterated with force in Resolution 5/X containing a declaration of sovereignty and claiming the right of the people of Catalonia to decide their political future in accordance with nine principles, and most importantly sovereignty understood as "the character of a sovereign political and legal subject". ${ }^{8}$

The path to independence was further defined by the Generalitat in a White Paper. ${ }^{9}$ The document is extremely comprehensive and was intended to guide the process of independence from popular consultations to the effective creation of a new State, passing through the declaration of independence and the adoption of a Constitution. It also deals with the succession of international treaties and the distribution of assets between Spain and the new State.

Without hesitation, the Constitutional Court declared Resolution 5/X unconstitutional and null as "only the Spanish People are sovereign, exclusively and indivisibly, no other subject or State body or any part of the people can be endowed with sovereign status by a public power". The Court also held that the "right to decide" cannot be considered unconstitutional if it is interpreted not as "a manifestation of a right of self-determination, or as an unrecognized attribution of sovereignty", but rather as a political aspiration in accordance with the Constitution and the principles of "democratic legitimacy", "pluralism" and "legality", all of which were expressly proclaimed in Resolution 5/X. ${ }^{10}$

In a subsequent decision, the Court further clarified that under Article 149.1.3 of the Constitution, international relations are understood as relations between international subjects and governed by international law. Accordingly, "any foreign action carried out by Autonomous Communities should be limited to actions that do not involve exercising this ius contrahendi, do not generate immediate and actual obligations vis-à-vis foreign public powers, do not affect the State's foreign policy, and do not entail its liability vis-à-vis foreign States or inter or supra-national organizations". ${ }^{11}$

The Constitutional Court's decisions notwithstanding, the Catalan parliament accelerated the process by adopting first Law 10/2014 ${ }^{12}$ and then decree 129/2014, ${ }^{13}$ providing for non-binding consultations, which took place on 9 November 2014. The President and some members of the Catalan Government were subsequently found responsible of grave contempt to the Constitutional Court and banned from office by Catalan High Court of Justice and Supreme Court. The provision of Law 10/2014 dealing with the referendum were eventually found unconstitutional, ${ }^{14}$ while decree

6 Explanatory Memorandum on Law 19/2017, at Law-19_2017-on-the-Referendum-on-Self-determination.pdf (gencat.cat) 3. See also Resolution 5/X, 23 January 2013.

7 Resolution 742/IX, 27 September 2012.

8 Resolution 5/X, supra n. 6.

9 Government of Catalonia, White Paper on the National Transition of Catalonia. Synthesis (2014).

10 STC 42/2014, 25 March 2014, Ground 3.

11 STC 46/2015, 5 March 2015, Ground 4.

12 Law 10/2014, 26 September 2014.

13 Decree 129/2014, 27 September 2014.

14 STC 31/2015, 25 February 2015. 
129/2014 was declared unconstitutional and null. ${ }^{15}$

The saga continued nonetheless with the adoption of Resolutions 1/XI, ${ }^{16}$ 263/XI ${ }^{17}$ and 306/XI. ${ }^{18}$ The first document announced "the start of the process to create an independent Catalan State in the form of a republic". The second prospected the "disconnection" with the law of the Spain and a "unilateral mechanism of democratic exercise" meant to activate the convening of the Constituent Assembly. ${ }^{19}$ The third proclaimed without any further elaboration the right to self-determination of Catalonia and defined the general political orientation of the Government of Catalonia.

All resolutions were declared unconstitutional and null by the Constitutional Court, respectively, in Judgements $259 / 2015,{ }^{20} 170 / 2015^{21}$ and 215/2016. ${ }^{22}$ In the first decision, in particular, the Court categorically rejected the reference to "sovereignty" and reiterated that "the sovereignty of the nation, vested in the Spanish people, necessarily entails the unity of the nation" as provided for in Article 2 of the Constitution. ${ }^{23}$

Meanwhile, Catalonia adopted Law 16/2014 on external action and relations with the European Union (Acción y del Servicio Exterior del Estado), ${ }^{24}$ which designed the projection of Catalonia at the international level through policies, actions, activities and initiatives with regard to the EU as well as non-EU governments and other international organisations.

Law 16/2014 was challenged by the Spanish government before the Constitutional Court. Several provisions of the law were declared unconstitutional. ${ }^{25}$ The decision offered the Constitutional Court the opportunity to admit and delimit the external projection of Catalonia, while unambiguously reiterating the unity and territorial integrity of Spain.

In turn, the Spanish parliament adopted Law 15/2015 aimed at the effective enforcement of the judgments of the Constitutional Court. ${ }^{26}$ The law was considered constitutional in two appeals made by the Governments of Catalonia ${ }^{27}$ and Basque region. ${ }^{28}$ The Court pointed out that the measures aimed at enforcing its decisions were not peculiar to non-compliance by Autonomous Communities but could equally apply to the central authorities.

On 6 September 2017, the Catalan Parliament promulgated Law 19/2017, providing for a binding referendum on self-determination. According to Article 2, "[t] he people of Catalonia are a sovereign political subject and, as such, exercise its right to freely and democratically decide upon their political condition". ${ }^{29}$ Although Law 19/2017 was suspended by the Constitutional Court the day following its adoption, the Catalan Parliament adopted Law 20/2017, on "Juridical Transition and founding of the Republic". ${ }^{30}$ The law was intended to allow Catalonia "to function immediately and with

STC 32/2015, 25 February 2015.

Resolution 1/XI, 9 November 2015.

Resolution 263/XI, 27 July 2016.

Resolution 306/XI, 6 October 2016.

Para 7.

STC 259/2015, 2 December 2015.

STC 170/2016, 6 October 2016.

STC 215/2016, 15 December 2016.

Ground 4, relying on decision 42/2014, supra $\mathrm{n} .10$.

Law 16/2014, 4 December 2014.

STC 268/2014, 22 December 2016.

LAW 15/2015, 16 October 2015.

STC 215/2016, 15 December 2016.

STC 185/2016, 3 November 2016.

Law 19/2017.

Law 20/2017. 
maximum effectiveness" in the transitional period between the referendum on self-determination and the adoption of the Constitution by the Constituent Assembly. Defined as the supreme law of the Catalan legal system (Article 3), Law 20/2017 resembles to the typical constitution of a modern State, although it contains some features of authoritarian national populism including the power of the President of the Generalitat to appoint and remove the judiciary. ${ }^{31}$

It is composed of 89 articles plus the final provisions. The general provisions (Title I) proclaimed inter alia the constitution of the Catalan State (Article 1) and the national sovereignty of the people of Catalonia (Article 2). Article 4 dealt with the internal status of European Law and international law. The same provision declared the commitment of Catalonia to comply with international law. The sovereignty of Catalonia territory was to be exercised, under Article 6, within the territory of Catalonia as well as its airspace and maritime zones in accordance with the law of the sea. Articles 14 and 15 further established the continuation of the application of, respectively, European Law and international treaties.

Law 20/2017 too was suspended by the Constitutional Court on 12 September 2017. Nonetheless, the Catalan Parliament went ahead with the referendum, despite serious clashes between segments of the local population and the police. The election campaign was not neutrally overseen, nor the census and the vote counting submitted to a rigorous control. According to the authorities of Catalonia, however, $92,01 \%$ of voters were in favour of the independence of Catalonia, while the turnout was 43,03\%. On 10 October, the President of Catalonia assumed "the mandate of the people whereby Catalonia becomes an independent State" but proposed the Catalan Parliament to suspend the effects of the referendum and to engage in dialogue with the central government.

The same day, the MPs of the pro-independence bloc, who defined themselves as the "legitimate representatives of Catalonia", issued a declaration of independence, which was approved by the Catalan parliament on 27 October 2017. The declaration invoked the right to self-determination as recognised in international law and exercised through the referendum. It then declared "the suspension of self-government in Catalonia and the application of a de facto state of exception" and proclaimed the Catalan Republic, as an "independent, sovereign, democratic, social State under the rule of law". Finally, it pledged to enter negotiations with the Spanish State, on a foot of equality and without preconditions, in order to establish a collaborative framework for the benefit of both parts. ${ }^{32}$

The Constitutional Court unanimously declared null and unconstitutional both the Law on Referendum, ${ }^{33}$ and the Law of Juridical Transition. ${ }^{34}$ It held unambiguously that the Constitution obviously does not recognize any right to unilateral secession. Quite the contrary, the law on referendum was deemed inconsistent with several articles of the Constitution, including Articles 1.2 and 2 dealing, respectively, with national sovereignty being vested in the Spanish people, the indissoluble unity of the Spanish Nation, and the guarantee of the right to autonomy of the nationalities and regions composing Spain.

The decision also touched upon international law from three perspectives. First, it observed that reliance on the international treaties and resolutions referred to in the Law was entirely misplaced, since these instruments clearly confine the right to unilateral secession to the colonial context. Second,

31 A. Queralt Jiménez, 'The Populist Drift of the Catalan Pro-independence Movement', in J.A. Kämmerer, M. Kotzur, J. Ziller (eds.), Integration and Desintegration in Europe (Baden Baden: Nomos, 2019) 253.

32 More information here.

33 STC 114/2017, 17 October 2017.

34 STC 124/2017, 8 November 2017. 
and for the sake of argument, the Court held that a treaty hypothetically providing for unilateral secession outside the colonial context could not become part of domestic law, or be applied within the jurisdiction of Spain, since it would be contrary to the Constitution. Third, the Court emphasised that Article 4.2 of the Treaty Establishing the EU protects inter alia the territorial integrity of the member States.

On 17 October, the central government for the first time triggered the application of Article 155 Constitution, which led to the adoption of a series of serious measures, including the dismissal of the President and the Catalonia Government. His functions were assumed by central authorities. ${ }^{35}$ On 27 October, the President and some members of the Catalan Government fled to Belgium, while the Vice-President and other members were arrested and charged with several criminal offences. The later were eventually found guilty of sedition and misuse of public funds and sentenced by the Supreme Court. ${ }^{36}$

The Catalan declaration of independence met the firm dismissal of the European Union (EU) ${ }^{37}$ and its members, as well as virtually all States. ${ }^{38}$ The Commission immediately declared that the referendum "was not legal. [...] If a referendum were to be organised in line with the Spanish Constitution it would mean that the territory leaving would find itself outside of the European Union". ${ }^{39}$ The President of the Parliament echoed it by defining the declaration of independence as "a breach of the rule of law, the Spanish Constitution and the Statute of Autonomy of Catalonia, which are part of the EU's legal framework" and warning that no one in the EU would recognise it". ${ }^{40}$

\section{(C) CLAIM TO INDEPENDENCE}

The legal basis of Catalonia's claim to independence has not been the object of a specific legal document or legal opinion by the authorities of Catalonia. Rather, the legal argument underpinning the independence claim must be construed through the relevant elements contained in the numerous legal and political documents adopted throughout the crisis. Such argument has been developed along two intertwined axes, namely the right to self-determination and the right to decide. The invocation of the "imprescriptible and inalienable right to self-determination" dates back at the latest to 1989 and was almost systematically reiterated in every subsequent legal or political documents. Yet, the solemn proclamation of the right was not supported by any specific legal argument. The right to decide, in turn, was formally introduced in 2013, and associated with several principles and most prominently "sovereignty". ${ }^{41}$

It appears that the White Paper published by the Catalan Government in 2014 was the first attempt to articulate the legal claim to independence. According to the document, the process towards independence is grounded on "three main principles": (a) self-determination in application of a

35 Order PRA/1034/2017 Section A. See M.J. García Morales, 'Federal Execution, Article 155 of the Spanish Constitution and the Crisis in Catalonia', 73 ZOR (2018) 791.

36 Supreme Court, Criminal Chamber, Judgment No. 459/2019, 14 October 2019. English translation available. See Agora, Catalonia Secession before the Spanish Supreme Court, 24 SYbIL (2020) 272.

37 See R. Caplan, Z. Vermeer, 'The EU and Unilateral Secession: The Case of Catalonia', 73 ZOR (2018) 474.

38 See, for example: State Department, Press Statement, 27 October 2017, according to which "Catalonia is an integral part of Spain, and the United States supports the Spanish government's constitutional measures to keep Spain strong and united"; United Kingdom, Statement on UDI made by Catalan Regional Parliament: 27 October 2017.

39 European Commission, Statement on the Events in Catalonia, Brussels, 2 October 2017.

40 European Parliament President, Statement on the situation in Catalonia, 27 October 2017.

41 See Resolution 5/X, supra n. 6. 
democratic principle; (b) self-determination as an inalienable right of a national community; and (c) self-determination as the last resort to remedy an unjust situation". ${ }^{42}$ The document is drafted in terms of "defence" or "justification" of the process of self-determination. It refrains from defining selfdetermination, identifying its legal foundations, holders and content, or explaining how it may be invoked by Catalonia to break away from Spain. Instead, it looks at self-determination from three different perspectives.

The first perspective construes self-determination as a response to the democratic principle to be exercised by a "unit of collective decision-making (demos)", which includes the ability to decide to become such "unit", combined with the right of individuals in a "regional collective" to set up an independent State, provided that certain conditions are satisfied (including economic and political viability, protection of minorities). The second perspective considers the right to self-determination in two sequential steps: "first, because of its status as a nation, as a national community is the ultimate repository of its sovereignty, and secondly, in application of the democratic principle, as this community has the right to exercise this sovereignty". The third perspective relates to remedial secession, which according to some States and scholars may be permitted under international law in situations of massive and systematic violations of human rights. In the context of Catalonia's claim to independence, those situations were placed in "descending order of doctrinal agreement" and featured at the first three places: "massive violations of human rights; unfair military annexations and occupations, especially those that took place after the express ban on territorial conquest wars in 1945; and "violations by the central Spanish State of the aspirations of self-governance and internal agreements on regional autonomy". ${ }^{43}$

The document later explained that the legality or legitimacy of a consultation may be reinforced by "rights and principles" of EU and international law, such as the democratic principle, the right to selfdetermination, and the protection of national minorities. It nonetheless conceded that the three rights and principles were "more as value and principles than rights in the strict sense". ${ }^{44}$

The official Explanatory memorandum attached to Law 19/2017 offered a more sophisticated attempt to define the legal claim to independence. It considered the referendum as an exercise of the right to self-determination guaranteed under the Charter of the United Nations and the 1966 UN Covenants, all ratified by Spain and now part of domestic law. It also referred to the right to democracy proclaimed by the UN, ${ }^{45}$ and relied on unidentified "recent opinions" by the ICJ, which are construed as holding that

\footnotetext{
"during the second half of the 20th century, there have been cases of new states that have exercised the right to self-determination without the exercise of this right to decide being motivated by the end of imperialism. The Court notes that the right of peoples to decide has evolved, and that, to counter this evolution, no new rule or custom has arisen at an international level to prohibit these new practices. The only limitation on the right to decide that the Court regards as enforceable is the unlawful resorting to force or other serious violations of the rules of international law."46
}

Law 19/2017 itself combines the exercise of the right to self-determination through the referendum (Article 1) and the right of the people of Catalonia, as a sovereign political subject, to decide upon their political condition freely and democratically.

\footnotetext{
42 Supra n. 9, 19.

43 At 20.

44 At 26.

45 Supra n. 6.

46 At 2.
} 


\section{(D) CATALONIA PATH TOWARDS STATEHOOD}

From the standpoint of international law, the first question to be addressed, relates to how far Catalonia has gone in the process toward statehood. The Catalonia bid to independence was marked by a crescendo of declarations on "the process to create an independent State" and on the ambition of becoming a "new State of Europe", which culminated in the proclamation of a "sovereign political subject". Several documents also addressed the question of statehood and referred to the requirements set by the 1933 Montevideo Convention.

The 2014 White Paper, in particular, expressly mentioned "a legitimate authority [that] exercises its competences effectively over the population and territory", but conceded that "in the event that the process is not fully agreed, some temporary problems with overlapping authority and territorial control may occur". ${ }^{47}$ The document also emphasised the importance of recognition, which could be sought even before the declaration of independence and may serve to demonstrate Catalonia's capacity to enter into relations with other subjects of the international community. ${ }^{48}$

(1) Statehood. In international law, attempts to define statehood systematically start by referring to Article 1 of the Montevideo Convention on the Rights and Duties of States. According to this Convention, a State as a person of international law should possess the following qualifications: (a) a permanent population; (b) a defined territory; (c) a government; and (d) the capacity to enter into relations with the other states. ${ }^{49}$ The definition is undoubtedly correct, but of limited assistance. It offers a static picture of statehood and fails to fully capture the factual and normally incremental process that leads to the creation (and conversely disappearance) of States.

A less famous but arguably more accurate description of the attributes of statehood was elaborated by the Permanent Mandate Commission in 1931 in relation to the independence of Iraq following the termination of the British mandate. According to the Commission, statehood requires (a) a settled Government and an administration capable of maintaining the regular operation of essential Government services; (b) capacity of maintaining territorial integrity and political independence; (c) ability to maintain the public peace throughout the whole territory; (d) adequate financial resources to ensure the performance of governmental functions; (e) laws and judicial organisation which will afford equal and regular justice to all. ${ }^{50}$

Indeed, the essence of statehood is a government exercising effectively and independently its authority. According to Judge Anzilotti, independence "is really no more than the normal condition of States according to international law; it may also be described as sovereignty (suprema potestas), or external sovereignty, by which is meant that a State has over it no other authority than international law". ${ }^{51}$ Likewise, Judge Huber held that "[s]overeignty in the relations between States signifies independence. Independence in regard to a portion of the globe is the right to exercise therein, to the exclusion of any other State, the functions of a State". ${ }^{52}$

It follows that statehood depends on factual circumstances rather than on constitutive elements. The English High Court held, with regard to the de facto government competing with the de jure government in the context of the Spanish Civil War (1936-1939), that "[t]he law, based on reality of

47 Supra n. 9.

48 At 124.

49 Concluded in Montevideo on 26 December 1933, into force on 26 December 1934, 165 LNTS 19.

50 Report to the Council, 9 - 27 June 1931, O. 4522. M, 176, 1931 VI.

51 Austrian - German Custom Union Case [1931], PCIJ, Ser. A/B, No. 41, p. 37.

52 Island of Palmas case, 2 UNRIAA (2006) 829, 838. 
facts material to the particular case, must regard as having the essentials of sovereignty a government in effective administrative control over the territory in question and not subordinate to any other government". ${ }^{53}$ This view is solidly supported in literature ${ }^{54}$ From this perspective, territory and population are the domain over which the government exercises its authority, rather than constitutive elements on their own. ${ }^{55}$ Accordingly, the absence of a clearly defined territory, ${ }^{56}$ do not necessarily prevent a government from being independent and effective. Likewise, variations of the territory and the population of a State do not affect statehood if the government continues to function independently and effectively. ${ }^{57}$ The capacity to enter into relations with other states is a consequence or a manifestation - rather than a constitutive element - of statehood. In all these regards, the declaratory element prevails over the constitutive one. But the latter is not wholly absent from the picture.

A useful distinction has been introduced between the rights inherent in statehood, which a government enjoys for the very fact that it exists, and the optional relations, which it may develop with other subjects of the international community. ${ }^{58}$ The first category includes rights which cannot be withhold and most notably the right to the inviolability of territorial integrity. ${ }^{59} \mathrm{~A}$ denial of such rights would encroach upon the sovereignty of the new subject. ${ }^{60}$ The optional relations are typically the exchange of diplomatic missions or the conclusion of treaties. It stands to reason that from the standpoint of timing, the inherent rights appear first and the optional rights develop later and on a case-by-case basis.

(2) Time and Process. By progressively interacting with other subjects of the international legal community, a State expresses its international legal personality. The State is then the holder of all rights and obligations it is capable to act upon. ${ }^{61}$ Consequently, it can bring and receive international claims in accordance with the law on State responsibility.

The independence of the United States offers an excellent example of the process. The 1776

53 England, High Court [Bucknill J.], Arantzazu Mendi [1938] L.R. 233, 245. The House of Lords [Lord Atkin], Arantzazu Mendi [1938] A.E.R. 267, held that "there is no difference for the present purposes between a recognition of a State de facto as opposed to de jure".

54 For T-C. Chen, The International Law of Recognition (New York: Green, 1951) 48, if a State "exists in fact, [it] must exists in law". J. Crawford, The Creation of States, $2^{\text {nd }}$ ed. (Oxford: OUP, 2006) 62, stresses that "[i]ndependence is the central criterion for statehood." See also G. Jellinek, Allgemeine Staatlehre, $3^{\text {rd }}$ ed. (Berlin, Häring, 1922) 332; G. Arangio-Ruiz, L'Etat dans le sens du droit de gens et la notion du droit international, 26 ÖZFOR (1975) 3; T. Grant, Recognition in International Law (Westport, London: Praeger, 1999); I. Brownlie, 'Recognition in Theory and Practice', 53 BYIL (1982) 197. See also the resolution adopted by the Institut de droit international, 30 Annuaire (1936) 300.

55 As emphasised by H. Lauterpacht, Oppenheim's International Law, $8^{\text {th }}$ ed. (London: Longmans, Green \& Co, $1955)$ 452, "[t]he importance of State territory lies in the fact that it is the space within which the State exercise its supreme authority." According to Crawford, supra n. 54, 52, "[t] he requirement of territory is rather a constituent of government and independence than a distinct criterion of its own". For J. Dugard, The Secession of States and their Recognition in the Wake of Kosovo (Leiden: Brill, 2013) 122, the territory is the "spatial context for the existence of the State".

56 See Permanent Court of International Justice, Monastery of Saint-Naoum, Advisory Opinion, 4 September 1924, Ser. B No 9.

57 G. Arangio-Ruiz, Sulla dinamica della base sociale nel diritto internazionale (Milano: Giuffrè, 1951), esp. para 47.

58 See S. Talmon, 'The Constitutive versus the Declaratory Theory of Recognition: Tertium non Datur?', 75 BYIL (2004) 101, 148-154, who relies on Hans Blix, Contemporary Aspects of Recognition, 130 RdC (1970) 587, 623.

59 Article 13 of the 1948 Charter of the Organisation of American States, expressly provides that "[t]he political existence of the State is independent form recognition by other States. Even before being recognised the State has the right to defend its integrity and independence", 119 UNTS 3, entered into force 13 December 1951, amended by Protocol of Buenos Aires, 721 UNTS 324.

60 See Talmon, supra n. 58, 153.

61 G. Arangio-Ruiz, Gli enti soggetti dell'ordinamento internazionale (Milano: Giuffè, 1951) 573. 
Declaration of independence contains at once the repudiation of any authority above the government of the thirteen colonies and the proclamation of the aspiration to become a new sovereign State, or an entity superiorem non reconoscens. ${ }^{62}$ Obviously, the declaration was not enough. The would-be government needed to concretely establish and exercise its effective and independent control over population and territory. The process leading to statehood was painfully achieved when at the end of the war the new independent and effective government imposed itself as the ruler the thirteen colony, eventually exercising physical power ${ }^{63}$ over them.

As independence and effectiveness are matters of degree, issuing a State with a birth certificate may be extremely difficult. Especially in the context of ongoing violence or precarious peace, assessing the stability and future prospects of an entity involves a delicate and unavoidably subjective judgment. ${ }^{64}$ In the Aaland Case, the Commission of Rapporteurs held that Finland could not be considered as a State until "a stable political organisation had been created, and until the public authorities had become strong enough to assert themselves throughout the territory of the State without the assistance of foreign troops". 65 The creation of States appears under this lens to be a process rather than an act, and its scrutiny an art more than a science.

(3) Legality. The fact that the creation of a State is a legal fact - and not a legal act ${ }^{66}$ - does not mean that the international community must assist powerless to the creation of the new subject, regardless to the circumstances in which this has occurred. The question of whether the new subject exists is independent from the possible consequences and reactions to how it has come into existence and how it behaves. As pointed out by Talmon, "[a]n international wrongful act does not prevent the creation of a State which is a question of fact, and a State which exists in fact attains its legal status solely on the basis of existence, independent of recognition". ${ }^{67}$

Yet, the creation of States does not occur in a vacuum. Other States and International organizations could react on the basis of political of legal considerations and ultimately influence or even determine the outcome of the entire process. ${ }^{68}$ On the one hand, the Security Council may resort to its powers under Chapter VII of the Charter in order to maintain and restore international peace and security, even in the absence of any breach of international law committed by the new government. ${ }^{69}$ It may impose non-military measures under Art. 41 of the Charter and even authorise member States or regional Organisations to take military action. It can also call for member States not to recognise the new subject, ${ }^{70}$ or enter into relation with or provide any assistance to it. The General Assembly may also recommend the latter set of measures.

On the other hand, States and International Organizations may react to breaches of international

62 Declaration of Independence, 4 July 1776.

63 As pointed out by Justice Holmes, McDonald v. Mabee, 243 U.S. 90, 91 (1915), "[t]he foundation of jurisdiction is physical power".

64 See Brownlie, supra n. 54, 206.

65 LNOJ Supplement No 4, 1920, 8-9. For H. Lauterpacht, Recognition in International Law (1947) 28, what is needed is "a sufficient degree of internal stability as expressed in the functioning of a government enjoying the habitual obedience of the bulk of the population".

66 G. Abi-Saab, 'Conclusions', in M.G. Kohen (ed.), Secession: International Law Perspectives (Cambridge: CUP, 2009) 471.

67 Talmon, supra n. 58, 180.

68 See Dugard, supra n. 55, 27.

69 H. Kelsen, The Law of the UN (New York: Praeger, 1950) 736.

70 As it occurred, for instance, with regard to Rhodesia, see SC resolution 216 (1965), 12 November 1965. In SC resolution 217 (1965), 20 November 1965, the declaration was considered as having "no legal validity". See also GA Res 2024 (XX), 11 November 1965. 
law committed by the new government by adopting countermeasures or any other measures permitted under international law. Moreover, under customary international law, they are obliged not to recognise when statehood has been achieved through violations of international law and peremptory norms. ${ }^{71}$ This is particularly important in the context of the use of force and self-determination. ${ }^{72}$

(4) Catalonia. Turning now to Catalonia, there is no doubt that statehood existed only on paper. The process toward the creation of a new State was ignited by solemn proclamations but was not followed by the concrete emergence and consolidation of an independent and effective government. Far from functioning as a sovereign entity, Catalan authorities continued to be subject to the effective authority of the central government, which eventually dismissed and replaced the Government of Catalonia and its President.

Even under the criteria of the 1933 Montevideo Convention, which was invoked in the White Paper, it is clear that no new State was formed. The criteria indicated in the Convention, namely the existence of a territory, a population, a government and the capacity to enter into relations with other international subjects belies any international legal personality. The absence of an independent government (superiorem non recognoscens) effectively exercising its jurisdiction over the population living in a given territory triggers the default on the last two of the requirements of the 1933 definition.

\title{
(E) TERRITORIAL INTEGRITY
}

The conclusion reached in the previous section that at no point an effective and independent government functioned in Catalonia means that the present inquiry should focus on the independence claim put forward by the Catalan authorities. If there is no new State, the discussion should switch to the claim to form a new one. To assess such a claim, however, it is necessary to examine preliminarily the principle of territorial integrity, which lies at the heart of the international legal order since the conclusion of the treaties of Westphalia (current section), and also the issue of recognition under international law (next section).

The treaties of Westphalia (1648) can be considered as the outcome of an incremental process leading to the creation of sovereign states entitled to freely organise themselves (internal dimension) without any interference from outside (external dimension). In this perspective:

\begin{abstract}
"[t]he state, as a spatial unit, results in the fundamental ordering of international relations through a central reliance on territorial conception. Respect for the boundary of states is crucial and results in derivative legal ideas of territorial jurisdiction, sovereign equality, and non-intervention. [...] Jurisdictional ideas about the reciprocal allocation of authority to govern territorially distinct units of space achieved great prominence through the logic of Westphalia."73
\end{abstract}

The principle was later proclaimed in Article 10 of the Covenant of the League of the Nations ${ }^{74}$ and Article 2.4 of the UN Charter, ${ }^{75}$ although in both cases from the standpoint of military force. It

71 Article 41, paragraph 2, 2001 Articles on Responsibility of States.

72 See J. Dugard, Recognition and the UN (Cambridge: CUP, 1987) $154 \mathrm{ff}$; Crawford, supra n. $54,107 \mathrm{ff}$.

73 R.A. Falk, 'The Interplay of Westphalia and Charter Conceptions of the International Legal Order', in R.A. Falk, C.E. Black (eds.), The Future of the International Legal Order (Princeton: PUP, 1969) Vol.1, 32, 43-44. See also A. Miele, La comunità internazionale, $3^{\text {rd }}$ ed. (Torino: Giappichelli, 2000) 6; S. Besson, 'Sovereignty', IX MPEPIL (2012) 366, 368; B. Fassbender, "Die Verfassungs- und völkerrechtsgeschichtliche Bedeutung des Westfälischen Friedens von 1648”, in I. Erberich et al. (eds.), Frieden und Recht (Stuttgard: Springer, 1998) 21-33.

74 See A. Verdebout, 'Article 10', in R. Kolb (ed.), Commentaires sur le Pacte de la Société de Nations (Bruxelles: Bruylant, 2015) 425.

75 See A. Randelzhofer, O. Dörr, 'Article 2(4)', in B. Simma et al. (eds), The Charter of the UN. A Commentary, $3^{\text {rd }}$ 
eventually found a full treatment, also in respect of the right to self-determination, in a series of General Assembly resolutions, most importantly Resolution 1514, according to which "any attempt aimed at the partial or total disruption of the national unity and territorial integrity of a State or country or at its political independence is incompatible with the purposes and principles of the Charter" 76 and 1970 Declaration on Principles of International Law concerning Friendly Relations and Cooperation among States, which reiterated that " $[\mathrm{t}]$ he territorial integrity and political independence of the State are inviolable". ${ }^{77}$

More recently, in the Millenium Declaration, UN member States formally declare: "we rededicate ourselves to support all efforts to uphold the sovereign equality of all States, respect for their territorial integrity and political independence, $[\ldots]$ the right to self-determination of peoples which remain under colonial domination and foreign occupation, non-interference in the internal affairs of States". ${ }^{78}$ The International Court of Justice held that respect for territorial integrity between independent States "is an essential foundation of international relations", ${ }^{79}$ or "an important part of the international legal order", enshrined inter alia in the UN Charter and in particular in Article 2, paragraph $4{ }^{80}$ Importantly for the purpose of this inquiry, it also held that "the principle of territorial integrity is confined to the sphere of relations between States". ${ }^{81}$

To appreciate how deeply the principle of territorial integrity is rooted in the legal conscience of States, it suffices to look at the legal stand taken by them in the context of the Kosovo advisory opinion. States typically declared that "respect for territorial integrity is an integral component of the principle of sovereignty recognised under international law. The guarantee of the territorial integrity of States ensures the stability of the international order"; 82 "the principle of respect for State sovereignty and territorial integrity [...] has constituted the most important principle of international law and the basic norm governing international relations"; 83 "respect for the sovereignty and territorial integrity of States is inscribed in the essential, non-derogable core of the basic principles of international law"; 84 "[t]he principle that states should respect the sovereignty and territorial integrity of other states is axiomatic and applies to all states"; 85 and "respect for the territorial integrity of States is a wellestablished principle of international law, without which the very existence of international law, as a corpus of rules governing primarily the relationship among sovereign entities, could not be

ed., (Oxford: OUP, 2012) 200.

76 GA Res. 1514 (XV), 14 December 1960, Para 6. The principle was clearly reaffirmed in Res. 2625 (XXV), 24 October 1970, preamble, as well as Res. 71/292, 22 June 2017 (Request for Chagos Archipelago advisory opinion, infra n. 112).

77 GA Res. 2625 (XXV), Annex. See G. Arangio-Ruiz, The Normative Role of the general Assembly of the UN and the Declaration of Principles of Friendly Relations, 137 RdC (1972-III) 137, 419. See also Helsinki Final Act, 1 August 1975, I (a) IV.

78 GA Res. 55/2, 8 September 2000, para 4. See also GA RES. 60/1 (World Summit Outcome), 24 October 2005, para 5 .

79 Corfu Channel Case, I.C.J. Reports 1949, Judgment, p. 35.

80 Accordance with International Law of the Unilateral Declaration of Independence in Respect of Kosovo, Advisory Opinion, I.C.J. Reports 2010, p. 403, para 80.

81 Ibidem. See also Legal Consequences for States of the Continued Presence of South Africa in Namibia (South West Africa) notwithstanding Security Council Resolution 276 (1970), Advisory Opinion, I.C.J. Reports 1971, p. 16, paras. 5253; East Timor (Portugal v. Australia), Judgment, I.C.J. Reports 1995, p. 102, para. 29; Legal Consequences of the Construction of a Wall in the Occupied Palestinian Territory, Advisory Opinion, I.C.J. Reports 2004, p. 136, para. 88).

82 Switzerland, Written Statement, 25 May 2009, para 54.

83 China, Written Statement, 16 April 2009, p. 3.

84 Spain, Written Statement, 14 April 2009, para 25.

85 United States, Written Statement, 17 April 2009, 69. 
envisaged". 86

\section{(F) RECOGNITION}

A constant concern of the Catalan authorities was to obtain the international recognition of Catalonia. The nature and legal effects of international recognition have been debated by generations of international lawyers and need to be concisely recalled. ${ }^{87}$ The debate on recognition has revolved essentially around two main and opposite theories.

(1) Constitutive or Declaratory? According to the constitutive theory (or status-creating), recognition is an indispensable element for the existence of a State. ${ }^{88}$ This theory is in great part an expression of an outdated, positivist view of the international legal order as a purely consensual system. ${ }^{89}$ It presents several problems. What is the status of an entity that is recognized by some but not all other States, like currently it is the case of Kosovo $?^{90}$ Does it exist only in bilateral relations? This relative existence is not easy to manage in a modern, interconnected world, which is not any more the one of the XIX century. Furthermore, States may refuse to recognise the new entity not only because they do not believe it is independent and effective, but also for political reasons.

Besides, as the practice of States shows, the existence of the new entity cannot simply be ignored in legal affairs, even if recognition is withheld. Thus, it may be necessary: (a) to establish the international responsibility of the unrecognized entity; (b) to allow the circulation and recognition of certain private acts concluded within the jurisdiction of the non-recognised entity; and (c) to protect the inhabitants of the non-recognised entity in accordance with international law. ${ }^{91}$ However, the rejection of the constitutive theory does not mean that with regard to certain legal positions recognition may not have constitutive status. ${ }^{92}$ The point here is that recognition does not create the State in itself or in conjunction with some other constitutive elements. Conversely, collective nonrecognition may indeed preclude the enjoyment of statehood in the international community, as is the case with the so-called Islamic State. ${ }^{93}$

According to the declaratory theory (or status-confirming), the State exists regardless of its international recognition. This view is today largely accepted and reflects State practice. ${ }^{94}$ As maintained by the Arbitral Commission of the Conference on Yugoslavia, "[ $t]$ he existence or disappearance of a State is a question of fact". ${ }^{95}$ Membership in a horizontally structured legal

86 Argentina, Written Statement, 17 April 2009, para 69.

87 For a sceptical view about the entire debate, see Brownlie, supra n. 54, 197.

88 See, in particular, L. Oppenheim, International law (1905); D. Anzilotti, Corso di diritto internazionale (Roma Athenaeum: Rome, 1928) 147 ff.; H. Kelsen, 'Recognition in International Law', 35 AJIL (1941) 605; Lauterpacht, supra n. 65 .

89 Talmon, supra n. 58, 102.

90 According to the Kosovo Ministry of Foreign Affairs, currently 114 States recognise Kosovo. Text here.

91 ECtHR, Cyprus v. Turkey, 2001, Application no. 25781/94, Judgment, 10 May 2001, para 42-46.

92 E.g. for treaty relations, diplomatic relations, the use of peaceful settlement of dispute mechanisms, etc.

93 See O. Corten, 'L'Etat islamique, un Etat? Enjeux et ambiguïtés d'une qualification juridique', in F. Safi et al. (eds.), Daech at le droit (Paris: LGDJ, 2016) $53 \mathrm{ff}$.

${ }_{94}$ See, Brownlie, supra n. 54, 205; R.Y. Jennings, A. Watts, Oppenheim's International Law, $9^{\text {th }}$ ed. (London: Longmans, 1992) 126; Chen, supra n. 54; J. Charpentier, La reconnaissance internationale et l'évolution du droit de gens (1956); Talmon, supra n. 58; Crawford, supra n. 54, 26-27. See also the IDI resolution, supra n. 54.

95 Opinion 1, in 31 ILM (1992) 1494. According to Abi-Saab, supra n. 66, 470, "[t] he State in the contemplation of international law is not a mere legal or 'juristic' person (personne morale), whose process of coming into being is prescribed by law. It is rather a 'primary fact', i.e. a fact that precedes the law, and which the law acknowledges only once it has materialised, by attributing certain effects to it, including a certain legal status". 
community, such as the international legal order characterized as it is by the absence of any authority superior to States, does not depend on any acts by other subjects.

(2) Question of Fact and Discretionary Nature. Statehood remains essentially a question of fact. The People Republic of China (PRC) has unquestionably been a State since the establishment of an effective and independent government, which emerged during the civil war. The PRC was eventually proclaimed in 1949. The fact that several States did not recognize it for more than two decades did not undermine its statehood. Indeed, the PRC was treated as a State despite lack of recognition. For example, non-recognition did not prevent the United States from bringing before 1979 international claims against the PRC. ${ }^{96}$

Recognition is a discretionary political act, although one carrying important political and legal consequences. ${ }^{97}$ The very fact that States have sometimes imposed conditions on the granting of recognition confirms that they did not feel obliged to recognize the new entity merely because of the existence of an independent and effective government. ${ }^{98}$ Politically, recognising or not recognising an entity claiming independence may hugely influence the conduct of all actors involved, and in the case of secession of the parent State.

(3) Premature Recognition. There is a settled rule of international law prohibiting premature recognition when the new entity has not yet established a sufficiently stable and effective government and is not fully independent. ${ }^{99}$ The issue arises mainly in the context of secession. Such premature recognition is considered as an unlawful intervention in the internal affairs of the parent State, from which the new entity has not yet fully separated. It may be unclear at what time exactly a new entity has attained a sufficient independence. For instance, some considered that the recognition of Kosovo in 2008 was precipitate. Premature recognition may cause diplomatic protest and possibly originate international disputes.

(4) Legal Effects. Recognition has important legal effects. In the first place, it certifies the perception by the recognising States on the statehood of the newcomer and contributes to stabilize the legal situation. ${ }^{100}$ Recognition also paves the way to the establishment of diplomatic relations and facilitates the conclusion and implementation of treaties. It renders the new situation opposable to the recognizing State, ${ }^{101}$ especially with regard to possible territorial claims. In the context of such specific legal positions, recognition is "constitutive". Thus, when considering the question under the double lens of statehood and of the specific legal positions of the new entity, recognition is declaratory

96 In 1954, for instance, the United States protested with the PRC for the shooting down of a British aircraft in which three US citizens were killed as well as for the military operations preventing the humanitarian rescue operations. The US considered the PRC in breach of international law and sought inter alia compensation and assurances of non-repetition, see Department of States Press Release, 27 July 1954, in M. Whiteman, Digest of International Law, Vol. 2 (Washington, 1963) 650-1.

97 There is no duty of recognition, as sometimes maintained in literature, see, for instance, Lauterpacht, supra n. 65. Brownlie, supra n. 54, 209, however, warns that "if an entity bears the marks of statehood, other States put themselves legally at risk if they ignore the basic obligations of State relations".

98 European Community, Declaration on Yugoslavia and on the Guidelines on the Recognition of New States, 16 December 1991, 31 ILM 1485 (1991).

99 See Jennings, Watts (eds.), supra n. 94, 143 ff; J. Verhoeven, La reconnaissance internationale dans la pratique contemporaire (1975), $566 \mathrm{ff}$. On premature recognition as unlawful intervention, see C. Tomuschat, International Law: Ensuring the Survival of Mankind on the Eve of a New Century, 281 RdC (1999) 236.

${ }^{100}$ In Reference Re Secession of Quebec [1998] 2 R.C.S., para 155, Canadian Supreme Court observed that "the ultimate success of a secession would be dependent on recognition by the international community".

101 See Charpentier, supra n. 94, 217 ff. 
in certain respects and constitutive in others. ${ }^{102}$

(5) Catalonia. The attempt made by the Catalan authority to detach recognition from statehood, in the sense that recognition could be sought before the definitive acquisition of international legal personality, is unpersuasive. The EU and its member States, as well as all other States, correctly refrained from recognizing Catalonia and emphasised the imperative need to respect the territorial integrity of Spain. Even before any consideration on territorial integrity, the evident absence of any independent and effective government instantaneously ruled out any possibility of granting Catalonia international recognition. This is not even a question of premature recognition. The question is that there was no entity to recognise. A hypothetical recognition would have been deprived of any legal effects from the standpoint of the relationships between the recognizing State and the entity recognised. Furthermore, it would also have amounted to an intervention in the domestic affairs of Spain.

\section{(G) SELF-DETERMINATION IN THE COLONIAL CONTEXT}

From an international law perspective, one of the most challenging questions raised in relation to the Catalan claim to form an independent State is the invocation of the right of peoples to selfdetermination. To assess such a claim, it is appropriate to discuss the origins, nature and content of the right to self-determination, both within the colonial context (current section) and outside it (next section), and then the question of unilateral secession (section I).

The origins of the right of peoples to self-determination can be traced back to the American Declaration of Independence. The Thirteen Colonies rejected any authority above themselves and claimed the right to freely organize themselves internally and to enter into relations with other States on an equal footing. In other words, they declared themselves to be a sovereign State. The declaration was obviously not enough. Statehood could be achieved either through an agreement with the British government, the authority exercising its jurisdiction over the population and the territory of the Thirteen Colonies, or by military force. In the second case, the effective creation of the new State would depend on the outcome of the hostilities.

At the end of the War of independence, the Washington government was the effective and independent ruler over the territory and population of the newly established United States. Through the conclusion of international agreements with other States - such as the Treaty of Amity and Commerce between the United States and France ${ }^{103}$ - the United States demonstrated its capacity to enter into relations with other States. Other States, conversely, recognized the new situation characterised by the creation of a new States.

At the beginning of the XX century, the right of peoples to self-determination found not only political recognition in President Wilson's Fourteen Points, ${ }^{104}$ but also concrete application in the bilateral treaties Russia concluded with the Baltic States for their independence. In the treaty with Lithuania, for instance, Russia recognised without reservation the sovereign rights and independence of the Lithuanian State on the bases of "the right of all nations to free self-determination up to their complete separation from the State into the composition of which they enter". ${ }^{105}$

102 See K. Zemanek, The Legal Foundations of the International System, 266 RdC (1997) 82-83.

103 Agreement, concluded on 6 February 1778.

1048 January 1918, Fourteenth point. Text here.

${ }^{105}$ Concluded on 12 July 1920, 3 LNTS 106 (Article 1) - UN translation. See also the treaties with Estonia, 2 February 
The right of peoples to self-determination was then formally proclaimed in Art. 1.2 and Art. 55 of the UN Charter. ${ }^{106}$ With the Charter, self-determination was elevated from political postulate to an inchoate "legal standard of behaviour". ${ }^{107}$ From the very beginning, however, it was made clear that the right to self-determination could not be construed as to undermine international borders and destabilize the international legal order. During the San Francisco Conference, self-determination was understood as implying "the right to self-government of people and not the right of secession". ${ }^{108}$ Moreover, self-determination did not at that time extend to colonial peoples. ${ }^{109}$

Subsequently, the vague proclamation of self-determination in the Charter was translated in concrete customary and treaty norms, and celebrated in a multitude of resolutions and declarations, mainly in the colonial context. Two resolutions adopted by the General Assembly are of paramount importance. Resolution 1514 proclaimed that all peoples had the right to self-determination, by virtue of which they freely determine their political status, pursue their economic, social and cultural development, and achieve complete independence. ${ }^{110}$ Resolution 1541, adopted the following day, specified three modalities for the exercise of self-determination by Non-Self Governing Territories, namely: (a) emergence of a sovereign independent State; (b) free association with other States: or (c) integration with other States. ${ }^{11}$

In the advisory opinion concerning the Chagos Archipelago, the ICJ considered that Resolution 1514 (XV) reflects customary international law with regard to the right to self-determination. ${ }^{12}$ In East Timor v. Australia, the ICJ had already held that the right to self-determination is "one of the essential principles of contemporary international law" having erga omnes character. ${ }^{113}$ The International Law Commission and some authors have even qualified self-determination as a peremptory norm (jus cogens). ${ }^{114}$

These resolutions call for three important considerations. Firstly, the right of peoples to selfdetermination was tightly linked with the process of decolonisation, and in particular situations of peoples under colonial or other forms of alien domination or foreign occupation. Resolution 1514 $(\mathrm{XV})$, in particular, proclaimed "the necessity of bringing to a speedy and unconditional end colonialism in all its forms and manifestations". ${ }^{115}$ The limited application of the right was

1920 (Article II), 11 LNTS 30; and Latvia, 11 August 1920 (Article 2), LNTS 1965.

106 Amongst the numerous studies on self-determination, see M. Pomerance, Self-Determination in Law and Practice (The Hague: Nijhoff, 1982); H. Hannum, Sovereignty and Self-Determination (Philadephia: PPU, 1990); A. Cassese, SelfDetermination of People. A Legal Reappraisal (Cambridge: CUP, 1995); D. Raič, Statehood and the Law of SelfDetermination (Leiden: Brill, 2002); F.R. Tesón (ed.), The Theory of Self-Determination (Cambridge: CUP, 2016).

107 Cassese, supra n. 106, 43.

108 Commission I, General provisions, Summary Report of the 6th Meeting, 15 May 1945, UNCIO, Vol. VI, 296. The Aaland Island Questions, Report presented to the Council of the League of the Nations by the Commission of Rapporteurs, Doc. B.7.21/68/106 (1921) 28, reads in part: "To concede a minority, either or language or religion, or to any fraction of a population the right of withdrawing from the community to which they belong [...] would be to destroy order and stability within States and to inaugurate anarchy in international life; it would be to uphold a theory incompatible with the very idea of the State as a territorial and political unity".

109 See Chapter XI of the Charter. For the period before decolonization, M. Bourquin, L'Etat souverain et l'Organisation Internationale (New York: Manhattan Publishing,1959), 205 ff.

${ }_{110}$ GA Res 1514 (XV). See also Res 637 A (VII) 16 October 1952, para 1 and 2.

111 GA Res 1541 (XV), Principle VI.

112 Legal Consequences of the Separation of the Chagos Archipelago from Mauritius in 1965, Advisory Opinion, 25 February 2019, para 152. See also Kosovo advisory opinion, supra n. 80, para 142.

113 East Timor (Portugal v. Australia), Judgment, I.C.J. Reports 1995, p.102, para 29. See also Construction of the Wall, advisory opinion, supra n. 81, paras 155-156, Chagos Archipelago, advisory Opinion, supra n. 112, para 180.

1142001 Articles on Responsibility of States, Commentary to Art. 26, para 5. See also Crawford, supra n. 54, 101.

115 See also Western Sahara, Advisory Opinion, I.C.J. Reports 1975, p. 12, para 55. 
consistently upheld by the ICJ in a series of decisions and advisory opinions. In the Namibia advisory opinion, in particular, the ICJ declared the right to self-determination contained in the UN Charter applicable to all non-self-governing territories referred to in Chapter XI of the Charter. ${ }^{116}$ In the Kosovo advisory opinion, it emphasised that "[d]uring the second half of the twentieth century, the international law of self-determination developed in such a way as to create a right to independence for the peoples of non-self-governing territories and peoples subject to alien subjugation, domination and exploitation". 117

Secondly, the creation of an independent State through the detachment from the parent State was not the only option for the exercise of the right to self-determination, even if it became by far the most popular one. ${ }^{118}$ Secession was not automatic. ${ }^{119}$ It should not be equated to selfdetermination. ${ }^{120}$ Furthermore, since the Non-Self Governing Territories enjoyed a temporary special status (until the right to self-determination has been fully exercised), it is not accurate to describe the formation of independent States as instances of secession. Rather, as pointed out by Higgins, "there was no suggestion that the old colonial rules should stay in State X, with 'the people' seceding, but rather that the colonial rules should go. Secession was not in issue in this context". ${ }^{121}$

Thirdly, these resolutions are fully respectful of the principle of territorial integrity. They cannot be construed as to authorising or encouraging "any action that would dismember or impair, totally or in part, the territorial integrity or political unity of sovereign and independent States". ${ }^{122}$ Quite the contrary, "[a]ny attempt at the partial or total disruption of the national unity and the territorial integrity of a country is incompatible with the purposes and principles of the UN Charter", ${ }^{123}$ or, as recently maintained by the African Union (AU), the right to self-determination was intrinsically linked to the principle of territorial integrity. ${ }^{124}$

The territorial unit for the exercise of the right to self-determination was therefore the territory of the non-self-governing territories. ${ }^{125}$ In the Chagos Archipelago advisory opinion, the ICJ unambiguously held that "the peoples of non-self-governing territories are entitled to exercise their

116 Namibia Case, supra n. 81, p. 31.

117 Kosovo advisory opinion, supra n. 80, para 79. In Council v. Front Polisario, Case C-104/16, 21 December 2016, para 88, the European Court of Justice held that the principle of self-determination is "applicable to all non-self-governing territories and to all peoples who have not achieved independence yet".

118 T. Christakis, Le droit à l'autodétermination en dehors des situations de décolonisation (Paris: Découverte, 1999).

119 J. Crawford, 'State Practice and International Law in Relation to Unilateral Secession', in A.F. Bayefsky (ed.), Self-Determination in International Law. Quebec and Lessons Learned (The Hague: Kluwer, 2000) para 17.

${ }^{120}$ The British government, however, declared that "the right to self-determination equates automatically to a right to secession”, 14 February 1997, 68 BYIL 587 (1998).

${ }^{121}$ R. Higgins, 'Self-Determination and Secession,' in J. Dahlitz (ed.), Secession in International Law: Conflict Avoidance - Regional Appraisal (The Hague: Asser Press 2013) 21, 35. Crawford, supra n. 54, 39, further observes that Resolution 1514 "did not advocate or support unilateral rights of secession [...] except where self-determination was opposed by the colonial power".

${ }^{122}$ Resolution 2625 (XXV), supra $\mathrm{n}$. 77. This is part of the so-called safeguard clause, text supra $\mathrm{n}$. 200. See also Resolution 1573 (XV), 19 December 1960 and Resolution 1274 (XVI), 20 December 1961 (Question of Algeria). In Resolution 2066 (XX), 16 December 1965, para 4, the General Assembly invited the administering Power "to take no action which would dismember the Territory of Mauritius and violate its territorial integrity". In Resolution A/RES/2357, 19 December 1967, the General Assembly expressed deep concern over the continuation of policies aiming at the disruption of the territorial integrity territories entitled to self-determination.

${ }^{123} \mathrm{~A} / \mathrm{RES} / 50 / 6,24$ October 1995.

124 Written Statement, 15 May 2018, Chagos Archipelago, Advisory opinion, supra n. 112, para 181. See the previous Written Statement, 1 March 2018, esp. paras 143-157.

125 The preamble of GA Res. 1514 (XV) emphases that "[a]ll people have an inalienable right to complete freedom, the exercise of their sovereignty and the integrity of their national territory." 
right to self-determination in relation to their territory as a whole, the integrity of which must be respected by the administering Power". ${ }^{126}$ This is without prejudice to the possibility that the people of the concerned territory freely and genuinely decides otherwise.

This is also in line with the uti possidetis iuris doctrine developed in South America in the XIX century, ${ }^{127}$ as well as the decision taken by the AU in 1964 to maintain the colonial borders of the newly independent States. ${ }^{128}$ As pointed out by the ICJ in 1986 with regard to the conservation of colonial borders in Africa, uti possidetis iuris is "a general principle, which is logically connected with the phenomenon of the obtaining of independence, wherever it occurs. Its obvious purpose is to prevent the independence and stability of new States being endangered by fratricidal struggles provoked by the challenging of frontiers following the withdrawal of the administering power". ${ }^{129}$

Several specific obligations (or enforceable concomitant duties) ${ }^{130}$ corresponded to the right to self-determination: a negative obligation to cease all armed action or repressive measures directed against dependent peoples; another negative obligation to refrain from any forcible action which would deprive concerned peoples of the full enjoyment of their right to self-determination; and a positive obligation to adopt immediate steps to transfer all powers to the dependent peoples, in accordance with their freely expressed will and without any conditions, reservations or distinction as to race, creed or colour.

A distinct obligation is also imposed upon all States, namely the obligation not to recognize as lawful a situation created by violation of the right to self-determination, nor render aid or assistance in maintaining that situation, as the obligation to cooperate to bring such situation to an end through lawful means. ${ }^{131}$ This was echoed in the Construction of the Wall advisory opinion. The Court's argument was based on the erga omnes character of the obligations related to the right of selfdetermination, which trigger the duty incumbent upon all States "while respecting the UN Charter and international law, to see to it that any impediment, resulting from the construction of the wall, to the exercise by the Palestinian people of its right to self-determination is brought to an end". ${ }^{132}$ Although the content of the right to self-determination in the colonial context is sufficiently clear, its implementation has been problematic in a significant number of cases, including, in the past, Rhodesia and South West Africa, and currently Western Sahara. ${ }^{133}$

${ }^{126}$ Chagos Archipelago, Advisory opinion, supra n. 112, para 160. See also text supra n. 192. In the Quebec Case, supra n. 100, para 127, the Canadian Supreme held that the international law principle of self-determination "has evolved within a framework of respect for the territorial integrity of existing states."

127 See, in particular, M.N. Shaw, 'The Heritage of States: The Principle of Uti Possidetis Juris Today', 67 BYIL 75 (1996); G. Nesi, L 'Uti Possidetis Iuris nel diritto internazionale (Padova: CEDAM, 1996); S.R. Ratner, 'Drawing a Better Line: Uti Possidetis and the Borders of New States', 90 AJIL (1996) 590.

128 AHG/Res. 16(I), 1964.

129 Frontier Dispute, Judgment, I.C.J. Reports 1986, p. 554, 565.

130 T. Franck, in Bayefsky, supra n. 119, 75, 76.

1312001 Articles on Responsibility of States, Art. 26 (1) and (2).

132 Supra n. 113, para 157. Writing in 1995, Cassese, supra n. 106, 134, observed that "in actual practice, Stats have only seldom made use of their right to demand compliance with international standards on self-determination by a given States."

${ }^{133}$ In literature, see T. Franck, 'The Stealing of Sahara', 70 AJIL (1976) 694; M. Shaw, 'The Western Sahara Case', 49 BYIL (1978) 118; S. Simon, 'Western Sahara', in C. Walter et al. (eds.), Self-Determination and Secession in International (Oxford: OUP, 2014) 255. The UK Government has declared that it "does not recognize a de jure administering power in Western Sahara. Morocco exercises de facto control over part of the territory [...] The option for a referendum on the self-determination of Western Sahara, as set out in the UN Secretary General's 1990 report and the 1991 MINURSO mandate, have not changed. The United Kingdom fully support UN-led efforts to encourage Morocco and the Polisario Front to agree a lasting and mutually acceptable political solution that provides for the self-determination of the people of Western Sahara", HC Written Questions, 12 January and 20 November 2015, 86 BYIL (2015) 401. 


\section{(I) SELF-DETERMINATION OUTSIDE THE COLONIAL CONTEXT}

The UN Charter as well as several universal and regional human rights treaties, including the UN Covenants on Civil and Political Rights and on Economic, Social and Cultural Rights, ${ }^{134}$ and the African Charter on Human and Peoples' Rights, ${ }^{135}$ provide for the application of the right to selfdetermination to all peoples. ${ }^{136}$ This right has systematically been accompanied by reassurances that its exercise must be respectful of the territorial integrity of States. Outside the colonial context, all peoples were thus entitled to claim and enjoy the right of peoples to self-determination within the jurisdiction of their own State. Conversely, the right of peoples to self-determination could not be invoked to unilaterally alter international borders.

The 1984 General Comment 12 by the Human Rights Committee ${ }^{137}$ and, in even more eloquent terms, the 1996 General Recommendation by the Committee on the Elimination of Racial Discrimination, ${ }^{138}$ have reiterated that the right of self-determination has an internal dimension, granting to all peoples the right to pursue freely their economic, social and cultural development, as well as an external dimension, granting to all peoples in situations of colonialism, alien subjugation, domination, and exploitation the right to determine freely their political status.

Article 20 of the African Charter on Human and Peoples' Rights recognises the right of colonized or oppressed peoples to free themselves from the bonds of domination by resorting to any means permitted in international law. ${ }^{139}$ It also upholds their right to receive the assistance of the States parties to the convention in their liberation struggle against foreign domination. The practice and jurisprudence of the African Commission, however, amply confirm that Article 20 does not imply any departure from the traditional approach to self-determination, which permits secession only in the colonial context. ${ }^{140}$

In Congrès du people katangais v Democratic Republic of Congo, in particular, the Commission held that self-determination means "independence, self-government, local government, federalism, confederalism, unitarism or any other form of relations that accords with the wishes of the peoples but fully cognisant of other recognised principles such as sovereignty and territorial integrity". ${ }^{141}$ In a more recent case, while finding that the people of Southern Cameroon can legitimately claim to be a "people" for the purpose of Article 20, the Commission felt "obliged to uphold the territorial integrity of the Respondent State" and could not "envisage, condone or encourage secession, as a form of self-determination". ${ }^{142}$

(1) Definition of Peoples. Outside the colonial context, the right to self-determination suffers from

134 Resolution 2200A (XXI), 16 December 1966, entered into force, respectively on 23 March 1976, 999 UNTS 171, and 3 January 1976, 993 UNTS 3, Common Article 1.1.

135 African Charter on Human and Peoples' Rights, adopted 27 June 1981, entered into force 21 October 1986, OAU Doc. CAB/LEG/67/3 rev. 5, 21 ILM 58 (1982), Article 20.

136 See R. McCorquodale, 'Self-Determination: A Human Rights Approach', 43 ICLQ (1994) 857.

$137 \mathrm{HRI} / \mathrm{GEN} / 1 /$ Rev.9 (Vol. I). According to para 4, the realisation of the right to self-determination "is an essential condition for the effective guarantee and observance of individual human rights and for the promotion and strengthening of those rights" (emphasis added).

138 U.N. Doc. HRI $\backslash$ GEN $\backslash 1 \backslash$ Rev.6 at 209 (2003), para 4. See also Quebec Case, supra n. 100, para 126.

139 See R. Murrey, The African Charter on Human Rights and Peoples' Rights. A Commentary (Oxford: OUP, 2019), Article 20.

140 African Commission, Guidelines and Principles on Economic, Social and Cultural Rights in the African Charter on Human and Peoples' Rights (2010) para 41. See also Resolution on the situation of the North of the Republic of Mali, ACHPR/Res.217(LI)2012, 2 May 2012, points iv and ix.

141 Communication 75/92, 22 March 1995, para 5.

${ }^{142}$ Kevin Mgwanga Gunme et al. v. Cameroon, Case 266/03, 27 May 2009, para 190. 
two serious congenital deficiencies, namely the lack of any definition of "people", ${ }^{143}$ and, consequently, the lack of criteria to identify who is entitled to represent and speak on behalf of a "people". As pointed out by the Canadian Supreme Court, there is "little formal elaboration of the definition of 'peoples' which left the precise meaning of the term" open. ${ }^{144}$ A Group of Experts appointed by UNESCO has attempted to identify some characteristics inherent in a description (not a definition) of "people". They include: (a) a common historical tradition; (b) racial or ethnic identity; (c) cultural homogeneity; (d) linguistic unity; (e) religious or ideological affinity; (f) territorial connection; and (g) common economic life. ${ }^{145}$

The term "people" is then used as holders of the right to self-determination within the jurisdiction of a State. It may refer to regions, provinces, other territorial entities as well as minorities or indigenous peoples. This implies the concrete possibility of different (potentially overlapping) communities claiming to be entitled as "peoples" to exercise the right to internal selfdetermination. ${ }^{146}$ This could generate a complex legal framework with variable geometry in which each "people" may hold its own right to internal self-determination.

In spite of the indeterminacy of "people", it is generally accepted that the right of peoples to internal self-determination applies "within the territorial framework of independent States" 147 and refers to the legal relationship between a State and the subjects within its jurisdiction. ${ }^{148}$ From a theoretical point of view, peoples can be considered either as the holder or the beneficiaries of the rules protecting the right to self-determination. ${ }^{149}$ Either way, the attendant obligations for the realization of self-determination no doubt fall on States. ${ }^{150}$

(2) Content of the Right. In spite of the solemn proclamations, the precise content of this extended right to self-determination remains mysterious. ${ }^{151}$ In 1992, the European Community Arbitration Commission on Yugoslavia, conceded that "international law as it currently stands does not spell out all the implications of the right to self-determination". ${ }^{152}$ The content of the right to internal selfdetermination and the correlated obligations of States are difficult to be established in abstract terms as they can vary in space and time.

The ductility of the right to self-determination has been stressed by the African Commission according to which it may be exercised "in any of the following ways independence, self-government, local government, federalism, confederalism, unitarism or any other form of relations that accords with the wishes of the people but fully cognisant of other recognised principles such as sovereignty

${ }^{143}$ Writing in 1956, I. Jennings, The Appraisal of Self-Determination (Cambridge: CUP, 1956) 55-56, argued that "[o]n the surface it seemed reasonable: let the people decide. It was in fact ridiculous because the people cannot decide until someone decides who are the people".

${ }^{144}$ Quebec Case, supra n. 100, para 123.

145 International Meeting of Experts on Further Study of the Concept of the Rights of Peoples, Paris, 27-30 November 1989, SHS.89/CONF.602/7, para 22.

${ }^{146}$ Ibidem, para 23, "[i]t is possible that, for different purposes of international law, different groups may be a people".

147 M. Shaw, 'People, Territorialism and Boundaries', 8 EJIL 478 (1997).

148 R. Higgins, 'Postmodern Tribalism and the Right to Secession', in C. Brölman et al. (eds.), Peoples and Minorities in International Law (Dordrecht: Nijhoff, 1993) 31.

149 See Cassese, supra n. 106, 142-3.

${ }^{150}$ Cassese, supra n. 106, 141.

151 According to C. Drew, 'The East Timor Story: International Law on Trial', 12 EJIL (2001) 651, 658, the right to self-determination "is plagued by an excess of indeterminacy both in terms of scope and content".

152 Opinion 2, $31 \operatorname{ILM}$ (1992) 1496, 1497. For a critique on the opinion, see M. Craven, 'The European Community Arbitration Commission on Yugoslavia', 66 BYIL 333 (1995). 
and territorial integrity". ${ }^{153}$

Attempts by States and scholars to define internal self-determination have led to rather general assertions. In the context of the Kosovo advisory opinion, for instance, Germany maintained that "[i]nternal self-determination means enjoying a degree of autonomy inside a larger entity, not leaving it altogether but, as a rule, deciding issues of local relevance on a local level". ${ }^{154}$ Scholars, in turn, have referred to "the right of people to govern, that is to have a democratic system of government", 155 or "the right of people to choose their political status within a State, or of exercising a right of meaningful political participation". ${ }^{156}$ In 1995, Cassese observed that "both customary and treaty law on internal self-determination have little to say with respect to the possible mode of implementing democratic governance. Nor do they provide guidelines on the possible distribution of power among institutionalized units or regions. Still less they furnish workable standards concerning some possible forms of realizing internal self-determination, such as devolution, autonomy, or 'regional' selfdetermination". ${ }^{157}$ This conclusion seems to remain accurate more than 20 years later. ${ }^{158}$

It seems therefore appropriate to understand internal self-determination as a concept built up of all individual and collective human rights that allow "a people's pursuit of its political, economic, social and cultural development within the framework of an existing state". ${ }^{159}$ Such rights include typically freedom of expression, freedom of assembly, freedom of association, the right to take part in the conduct of public affairs, the right to vote in free elections. ${ }^{160}$

Under these circumstances, a pragmatic and flexible approach may be inescapable. The right to self-determination could be seen as an evolving umbrella concept - comparable to sustainable development ${ }^{161}$ - under which a comprehensive catalogue of human rights are exercised individually and collectively. From this perspective, the meaning of internal self-determination is built up by several heterogeneous rights related to the protection of minorities, ${ }^{162}$ the enjoyment of cultural and linguistic rights, the right to democratic governance, ${ }^{163}$ and so on.

153 Congrès du people katangais v DRC, supra $\mathrm{n} .141$.

154 Written Statement, 15 April 2010, 33. According to Article 3.1 of the Council of Europe, European Charter of Local Self-Government, 15 October 1985, "[1]ocal self-government denotes the right and the ability of local authorities, within the limits of the law, to regulate and manage a substantial share of public affairs under their own responsibility and in the interests of the local population".

155 A. Rosas, 'Internal Self-Determination', in C. Tomuschat (ed.), Modern Law of Self-Determination (Dordrecht: Nijhoff, 1992) 225, 232.

156 S. Joseph, J. Schultz, M. Castan, The International Covenant on Civil and Political Rights. Case, Materials and Commentary (Oxford: OUP, 2000) 103.

157 Cassese, supra n. 106, 332.

158 See P. Macklem, Self-Determination in Three Movements, in Tesón (ed.), supra n. 106110.

159 Quebec Case, supra n. 100, 126. As noted by Macklem, supra n. 158, 108, "[t] possibilities short of sovereign independence contemplated by internal self-determination ranges from guaranteed representation in the political institutions of the broader society to constitutional or legislative arrangements that secure a measure of autonomy for ethnic, cultural, and religious communities".

${ }^{160}$ In Quebec Case, supra n. 100, 126, the Canadian Supreme Court also referred to the "prominent positions" occupied by Quebecers in the central government".

161 According to V. Lowe, 'Sustainable Development and Unsustainable Arguments', in A. Boyle et al. (eds.), International Law and Sustainable Development (Oxford: OUP, 1999) 30, sustainable development is a "label for a general policy goal which may be adopted by states unilaterally, bilaterally, or multilaterally".

162 See F. Capotorti, Study on the Rights of Persons belonging to Ethnic, Religious and Linguistic Minorities, 1977 , UN Doc. E.91.XIV.2.

${ }^{163}$ See T. Franck, 'The Emerging Right to Democratic Governance', 86 AJIL (1992) 46. 


\section{(J) RIGHT TO SECESSION}

Secession can be defined as "the creation of a new independent entity through the separation of part of the territory and population of an existing State, without the consent of the latter". ${ }^{164}$ It is undisputed that parts of the territory of a State (i.e. a province or a region) may depart from the parent State with the consent of the later and provided that the decision reflects the genuine will of the majority of the population involved and is consistent with human rights. This is done by way of agreed separation. This is how Montenegro became a State in 2006. Article 60 of the 2003 Constitutional Charter of the State Union of Serbia and Montenegro granted each State the right, to be exercised upon the expiry of a three year period, "the right to initiate the proceedings for the change in its state status or for breaking away from the state union of Serbia and Montenegro". 165 This was indeed the outcome of the referendum held in Montenegro on 21 May 2006, which was followed by a Declaration of independence and the international recognition of Montenegro as independent State. ${ }^{166}$ This was thus a (lawful) separation and not a (violent) secession.

Some scholars have suggested to resolve the issue of secession by applying the "earned sovereignty" approach. ${ }^{167}$ Such approach is based on an articulated process through which national self-determination movements gradually acquire and exercise increasingly broader government powers up to - although not necessarily - complete independence. ${ }^{168}$ It may certainly be the most appropriate one for resolving sovereignty-based conflicts to the point of leading to full independence, if the territorial State is prepared to accept it. ${ }^{169}$ Being entirely based upon the agreement between the movement and the territorial State, however, it becomes inconsequential when the territorial State resists - possibly by force - the claim to full independence from a national movement. The question then is whether the unilateral claim to full independence is legally protected under international law. Whether a right to unilaterally secede - intended as a "positive entitlement", 170 "legally enforceable entitlement", ${ }^{171}$ or simply a "legally protected entitlement" - exists outside the colonial context requires an inquiry on State practice in search of a permissive customary rule, ${ }^{172}$ while keeping in mind that customary international rules are created and evolve through "a process of continuous interaction, of continuous demand and response". ${ }^{173}$

State practice indicates that a legal claim on unilateral secession outside the colonial context has not been clearly articulated by a significant number of States and has even less attracted the critical mass of acceptance, or at least acquiescence, indispensable to create a customary rule. Quite the contrary, States have consistently and massively opposed the invocation of self-determination outside the colonial context (or the quasi-colonial context of racist regimes and foreign occupation) as legal

${ }^{164}$ M. Kohen, Introduction, in Kohen (ed.), supra n. 66, p. 3.

165 Text here.

166 The same path would have been followed by Scotland, had the outcome of the 2014 referendum be in favour of independence.

167 Testimony of P.R. Williams, House Committee on Foreign Affairs, "U.S. Policy toward National SelfDetermination Movements", 15 March 2016, footnote 2 at p. 10.

${ }^{168}$ See P.R. Williams, F. Jannotti Pecci, 'Earned Sovereignty: Bridging the Gap between Sovereignty and SelfDetermination', 40 Stanford JIL (2004) 347.

169 Williams, supra n. 168,6

${ }^{170}$ Kosovo advisory opinion, supra n. 80, p. 56.

171 Report by T. Franck (Question 2), in Bayefsky, supra n. 119, para 2.1.

172 Since there are no applicable treaty rules. It is not sufficient that international law does not prohibit secession, since from an absence of prohibition no right to do something can be derived.

${ }^{173}$ M.S. McDougal, The Hydrogen Bomb Tests and the International Law of the Sea, 49 AJIL (1955) 353, 354 (1955). 
basis to alter territorial integrity - with the only and still rather controversial issue of remedial secession (see section X).

The international community of States has accepted as fait accompli the unilateral secession of a not insignificant number of States. Secession occurred in the context of internal conflicts and possibly in the context of State dissolution or dismemberment - as in the case of former Yugoslavia - or following external military intervention - as in the case of Bangladesh. It is not possible, however, to extrapolate from these cases the general acceptance of any legal claim or legal entitlement for the breakaway entity to obtain independence. The creation of States remains largely a question of fact, while secession is not prohibited by international law.

State practice does not manifest any significant acceptance by States of secession as a right under international law. As observed by the Canadian Supreme Court "international law does not specifically grant component parts of sovereign states the legal right to secede unilaterally from their 'parent' state". ${ }^{174}$ Likewise, the Independent International Fact-Finding Mission on the Conflict in Georgia held that "[o]utside the colonial context, self-determination is basically limited to internal self-determination. A right to external self-determination in [the] form of a secession is not accepted in state practice". 175

It is true that in recent instances of territorial entities breaking away from the parent State, States have not consistently and uniformly opposed the creation of the new State, or indeed even the annexation to another State. It has even been suggested that "a sizeable majority of States now accept the right of people to secede from existing under certain circumstances". ${ }^{176}$ The argument is based on the observation that many of the States that have opposed the Crimean "secession" had previously supported the Kosovo secession. Leaving for the moment aside the rather controversial exception of remedial secession, ${ }^{177}$ the cases of Kosovo and Crimea hardly support the view that the generality of States has accepted that the right to self-determination can be exercised to the point of claiming full independence.

In the case of Kosovo, a significant number of States openly rejected that Kosovo could exercise any legally enforceable (or legally protected) entitlement to statehood and proclaimed the sanctity of international borders in accordance with General Assembly resolution 2625. ${ }^{178}$ More importantly, the States not opposing the Kosovo secession carefully refrained from admitting any such legal entitlement.

In the case of Crimea, one hundred States voted in favour of the General Assembly resolution affirming the territorial integrity of Ukraine and calling upon all States to desist and refrain from action inconsistent with it. ${ }^{179}$ Several States supporting the resolution clearly reiterated that Crimea did not have a right to secede and the borders of Ukraine could be changed only through agreement and in accordance with human rights standards. ${ }^{180}$ Some of them even adopted countermeasures

174 Quebec Case, supra n. 100, para 111.

175 Report, vol II (September 2009) 141.

176 Y. Shany, 'Does International Law Grant the People of Crimea and Donetsk a Right to Secede?', 21 Brown Journal World Affairs (2014) 233. See also T.D. Grant, 'Annexation of Crimea', 109 AJIL (2015) 68.

177 Section J.

178 See, for instance, Kosovo advisory opinion, Written Statement by the Russian Federation, 16 April 2009, esp. para 19-22.

179 GA Res. 68/262, Territorial integrity of Ukraine, 1 April 2014.

180 See, in particular the intervention made by EU, A/68/PV.80, 3, 27 March 2014, 4; United States, 6; Liechtenstein, 7; Canada, 9; Japan, 10; Georgia, 11; Turkey, 11, China, 11; Iceland, 12; Norway, 14; Uruguay, 15; Saint Vincent and the Grenadines, 15; Guatemala, 18; Singapore, 18; Argentina, 18; Chile, 19; Qatar, 20; Thailand, 22; Moldova, 22; Peru, 
against the Russian Federation, expressly condemning the violation of Ukraine sovereignty and territorial integrity. ${ }^{181}$

Amongst the States voting against the resolution or abstaining from voting only the Russian Federation put forward a clearly articulated legal claim in favour of Crimea's entitlement to break away from Ukraine. ${ }^{182}$ There is little trace of any entitlement in the interventions of the other 10 States voting against and even less in those of the 58 abstaining from voting it.

The conclusion that "State practice since 1945 shows very clearly the extreme reluctance of States to recognise or accept unilateral secession outside the colonial context" 183 remains valid. Recent practice confirms rather than weakening such conclusion. As Judge Yusuf reminds us, the right of unilateral secession "would reduce to naught the territorial sovereignty and integrity of States and would lead to interminable conflicts and chaos in international relations". ${ }^{184}$ This view is overwhelming in literature. ${ }^{185}$

There is another important reason for which States have adamantly opposed the right to secede. It is extremely difficult to identify the holder of the right to secession and there is thus a risk of opening a Pandora box. Practical problems are manifold in this context. For example, why should the territorial entity breaking away, possibly based on some historical claims, be allowed to secede from the parent State, but not a minority within that entity, which would prefer to remain within the jurisdiction of the parent State or wishes to establish its own independent entity? Why should Croatia make a claim against former Yugoslavia and not the Krajina region against Croatia itself? ${ }^{186}$ Within the context of the claim of independence of Quebec, the aboriginal people Crees challenged the right of Quebec to secede not only because there is no such right under international law, but also because the independence of Quebec would violate their own right to self-determination. ${ }^{187}$

Yet, international law remains neutral or indifferent to the phenomenon of secession itself. As pointed out by the United States, the fact that the principles of sovereignty equality, political independence and territorial integrity "are axiomatic does not preclude entities from seeking to emerge or actually emerging as new states on the territory of the original state". ${ }^{188}$ This means that

22; Azerbaijan, 23; Jamaica, 24; Algeria, 24, Honduras, 25; Ecuador, 25, Botswana, 26; Libya, 26; Costa Rica, 27; Paraguay, 27.

${ }^{181}$ See, in particular, EU, Council Decision 2014/512/CFSP, OJ L 229/13, 31.7.2014, preambular paragraph 1. United States' President Executive Order 13660, 10 March 2014, Federal Register, Vol. 79, No. 46, refers to the threat to the sovereignty and territorial integrity of Ukraine.

182 The Russian Federation declared that it "could not refuse the Crimeans' wish to support their right to selfdetermination in fulfilling their long-standing aspirations. Historical justice has been vindicated. Crimea was an integral part of our country for several centuries. It shares with our country a common history, culture and, most important, a common people”, A/68/PV.80, 27 March 2014, 3.

183 J. Crawford, 'State Practice and International Law in Relation to Secession', 69 BYIL 85 (1998). See also, H. Gross Espiell, The Right to Self-Determination: Implementation of UN Resolutions, UN Doc. E/CN.4/Sub.2/405/Rev.1 (1980), esp. para 90.

${ }^{184}$ Separate Opinion, Kosovo advisory opinion, supra n. 80, para 10. Higgins, supra n. 148, 36, points out the right to unilateral secession trigger endless "disintegrative processes".

${ }^{185}$ See Crawford, supra n. 54, 415; T. Franck, R. Higgins, A. Pellet, M.N. Shaw, C. Tomushat, L'intégrité territorial du Québec dans l'hypothèse de l'accession à la souveraineté (English translation), in Bayefsky, supra n. 119, 241. Amongst the authors admitting a right to secede, see L. Brilmayer, 'Secession: The Morality of Political Divorce from Fort Sumter to Lithuania and Quebec', 16 YJIL (1991) 177; Buchanan, supra n. 119.

186 T.M. Franck, Fairness in the International Legal and Institutional System, 240 RdC (1993) 9, 136.

187 Factum of the Grand Council of the Crees (Eeyou Istchee), in Bayefsky, supra n. 119, 351.

${ }^{188}$ United States, Written Statement, supra n. 85, p. 69. In the same vein, the British Government, Written Statement, 16 April 2009, para 5.33, observed that international law "neither, in general, does it prohibit secession or separation, or guarantee the unity of predecessor States against internal movements leading to separation or independence with the 
secession remains "basically a phenomenon not regulated by international law". ${ }^{189}$ The principle of effectiveness operates here in the sense that the establishment of an independent and effective government may eventually be recognized as fait accompli. But effectiveness "is not a norm. It authorizes nothing and justifies nothing. In particular, it does not authorize secession as a matter either of right or privilege". ${ }^{190}$

This factual approach is without prejudice to the legal consequences that may be attached to violations of international law committed during the process leading to secession. As held by British Government in relation to the Kosovo advisory opinion, "there can be cases where separation or secession from a State raises issues of illegality under international law; indeed such cases can involve issues of fundamental concern. They may involve external aggression or intervention, or widespread violation of basic human rights". ${ }^{191}$ But the illegality does not relate to the claim of secession itself, but rather to the conduct the outcome of which is secession. Thus, a secession may be upheld by a use of force of a third State; it is then this use of force which makes the process illegal and prompts a duty of non-recognition.

It follows that Catalonia has no right under international law to break away from Spain. The right of self-determination does not confer any legal entitlement for the creation of new States, except in the context of colonialism, and even in this case only as one of the possible options available to the peoples. The practice of States and international organisations, including most importantly the UN and the AU, is unequivocally against a right to unilateral secession regardless to the unfairness of the State borders. The process of decolonisation itself has been conducted and is still conducted on the firm assumption that the right to self-determination must be exercised by the people living within the colonial borders, unless an agreement with the metropolitan States provides otherwise. The recent ICJ Chagos Archipelago advisory opinion has also confirmed that "[b]oth State practice and opinio juris at the relevant time confirm the customary law character of the right to territorial integrity of a non-self-governing territory as a corollary of the right to self-determination". ${ }^{192}$

The construction of the ICJ position on self-determination by Catalan authorities is inaccurate. ${ }^{193}$ In the first place, the ICJ has not referred to the "right to decide", but to the "right to selfdetermination". The immediate form of the exercise of the right to self-determination relates to the inalienable right of every State to choose its political, economic, social and cultural systems without outside interference. This is undisputed both in the practice of the UN and the jurisprudence of the ICJ. The right is understood as a manifestation of State sovereignty, not the possible legal entitlement of territorial entities to break away from a State. Further, in the Kosovo advisory opinion the Court did not hold - as alleged by Catalonia - that unlawful use of military force or other serious violations of international law are the only "enforceable limitation" to the right to decide. ${ }^{194}$ What the ICJ said was that the unlawful use of military force or other serious violations of international law make illegal

support of the peoples concerned". Likewise, Japan, Written Statement, 17 April 2009, 3, argued that “[i]nternational law, in general, neither approves nor prohibits secession or independence by an entity which meets the requirements of Statehood". According to G. Abi-Saab, in Bayefski, supra n. 119, 84, international law "permits secession and will recognize it if successful, but neither prohibits nor encourages it in non-colonial situations". See also Lauterpacht, supra n. 65,8 .

189 Abi-Saab, supra n. 66, 474.

190 Reply of the Attorney General of Canada, in Bayefsky, supra n. 119, 375.

191 Written Statement, 17 April 2009, para 5.34.

192 Chagos Archipelago, advisory Opinion, supra n. 112, para 160.

193 Section C.

194 Explanatory memorandum, supra n. 29, p 2. 
declarations of independence, when otherwise international law is indifferent to such declarations.

While not generally prohibited under international law, secession is clearly unlawful under the Spanish Constitution, ${ }^{195}$ as well as under other Constitutions. ${ }^{196}$ The Spanish Constitutional Court correctly drew a clear line separating "autonomy" and "sovereignty" as a matter of domestic law. ${ }^{197}$ For the purpose of this article, however, it suffices to note that internal self-determination becomes then essentially a matter of distribution of competences between central and local authorities.

\section{(K) REMEDIAL SECESSION}

The only possible, yet controversial, exception to legally justify the breaking away of a minority or territorial entity is the so-called remedial secession. The argument was hinted at already in the Aaland case, when the Commission conceded that a minority could consider separation from the parent State and incorporation into another "as an altogether exceptional solution, a last resort when the [parent] State lacks either the will or the power to enact and apply just and effective guarantee". ${ }^{198}$ The exceptional remedy was further developed in literature and expanded in order to include not only the possibility of incorporation into another State, but also the creation of a new State. Buchheit, in particular, maintained that depending on the level of oppression inflicted by a government upon a minority or territorial entity, "international law recognizes a continuum of remedies ranging from the protection of individual and collective rights to minorities rights, and ending with secession as the ultimate remedy". 199

The argument frequently relies on the so-called "safeguard clause" which has been inserted in Resolution $2625^{200}$ as well as in the 1993 Vienna Declaration. ${ }^{201}$ The clause has been interpreted $a$ contrario as admitting unilateral secession when the parent State does not comply with the principle of equal rights and self-determination of peoples. ${ }^{202}$ This reading of the resolution was shared in the context of the Kosovo advisory opinion by several States, including Switzerland ${ }^{203}$ and the Netherlands, ${ }^{204}$ as well as Judge Yusuf. ${ }^{205}$

The literal argument based on the "safeguard clause" is far from convincing. As clearly pointed out by Arangio-Ruiz, the clause "is meant to protect the political unity and the territorial integrity of all the parties duty-bound under this principle, namely all States, whether possessed of colonies or similar overseas territories or not; whether multi-national or multi-racial; whether monolithically compact in the ethnic composition of their peoples or ruling also over minority groups of different

\footnotetext{
195 Supra n. 1, Article 2.

196 For instance, Art. 5 of the Italian Constitution proclaims the unity of the Republic. See also Constitutional Court, Decision 118/2015, 29 April 2015, para 7.2.

197 The view that the right of autonomy "is not and cannot be mistaken for Sovereignty", as held by the Constitutional Court in the decision 124/2017, supra n. 34, Ground 5, is well settled in its jurisprudence, see in particular judgments 4/1981, 2 February 1981, Ground 3; and 25/1981, 14 July 1981, Ground 3.

198 Supra n. 108, 28.

199 L.C. Buchheit, The Legitimacy of Self-Determination (New Haven: Yale University Press, 1978) 222.

200 Supra n. 77, Principle 5, para. 7.

${ }^{201}$ World Conference on Human Rights, Declaration and Programme of Action, 12 July 1993, A/CONF.157/23, Point I.2.

202 Buchheit, supra n. 199, 93.

203 Written Statement, 25 May 2009, para 61.

${ }^{204}$ Written Statement, 17 April 2009, para 3.7.

205 Separate Opinion, para 12.
} 
origin, culture, or creed". ${ }^{206}$ This interpretation has been shared by several States in the Kosovo proceedings. ${ }^{207}$ It would be strange if a radical consequence, such as the one flowing from the recognition of a right of secession, was conceded tacitly by some $a$ contrario acrobatics linked to a potentially ambiguous text. This conclusion would be even more questionable when considering that the Resolution 2625 considered as sacrosanct the principle of territorial integrity and at any rate is recommendatory in nature.

Since there is no conventional basis for such a right, State practice and opinio juris must be assessed with a view of determining, from the standpoint of customary international law, the existence of a generally accepted legal claim to remedial secession. State practice is not dense and generally offers only marginal references to the right to secede and no legal claim seems to have been clearly articulated. ${ }^{208}$

The Kosovo advisory opinion, however, offered an incomplete, but quite reliable test on the alleged right to remedial secession. The test is incomplete since only 43 States participated in the written or oral phase of the proceedings and the Court limited itself to observe that differences existed regarding whether international law provides for a right of remedial secession and whether the circumstances which some participants maintained would give rise to such a right were present in Kosovo. ${ }^{209}$

A significant number of the States that have submitted written statements in these proceedings declared that in extreme circumstances the right to self-determination may be exercised to the point of claiming independence even outside the colonial context. ${ }^{210}$ According to Germany, for instance, self-determination "may exceptionally legitimize secession if this can be shown to be the only remedy against a prolonged and rigorous refusal of internal self-determination. This kind of remedial right of secession would not endanger international stability, as it would come into play only under circumstances where the situation inside a State has deteriorated to a point where it might be considered to endanger international peace and stability in itself'. ${ }^{211}$ These States have consequently articulated a legal claim according to which the right to self-determination could exceptionally be invoked beyond the colonial context in case of massive and systematic violation of fundamental rights. $^{212}$ Some States seem to have acquiesced to such a claim. The Russian Federation, in particular, admitted that secession could be permitted in "truly extreme circumstances, such as an outright armed attack by the parent State, threatening the very existence of the people in question". ${ }^{213}$ Other States have just mentioned remedial secession without taking position, ${ }^{214}$ or neglected it altogether. ${ }^{215}$

206 G. Arangio-Ruiz, The UN Declaration on Friendly Relations and the System of Sources in International Law (Alphen aan den Rijn: Sijthoff, 1979), para 80. Shaw, supra n. 147, 483, observes that "such a major change [in the protection of territorial integrity] cannot be introduced by way of an ambiguous subordinate clause".

207 See, for instance, Argentina, Written Statement, 17 April 2009, para 97.

${ }^{208}$ For a full analysis of these cases, see Dugard, supra n. 55, Chapter IV. See also A. Tancredi, La secessione nel diritto internazionale (Padova: CEDAM, 2001).

209 Supra n. 80, para 82 in fine. The Court reluctance to deal with remedial secession was criticised by Judge Simma, para 6, and Judge Yusuf, para 17.

${ }^{210}$ On the position of the 43 States participating in the proceedings, see M. Milanovic, 'Arguing the Kosovo Case', in M. Milanovic, M. Wood, (eds), The Law and Politics of the Kosovo Advisory Opinion (Oxford: OUP, 2015$) 21$.

${ }^{211}$ Written Statement, April 2009, p. 34.

212 J. Vidmar, Democracy and Statehood in International Law (Oxford: Hart, 2013) 168, has observed that remedial secession is "the last resort to end gross and systematic breaches of human rights" and emphasised that respect for human rights is quite different from implementation of democratic practices.

213 Written Statement, 16 April 2009, para 88.

${ }^{214}$ United Kingdom, Written Statement, 16 April 2009, para 5.30 - 5.33.

215 United States, Written Statement, 16 April 2009. 
There has also been significant opposition to the right to remedial secession. This was notably the case of Spain, according to which Resolution 2625 cannot be read in the sense that "respect for sovereignty and territorial integrity of States is subservient to the exercise of an alleged right to selfdetermination exercised via a unilateral act, and which is of great significance as regards the existence of personality under international law". ${ }^{216}$ China made a similar claim. ${ }^{217}$

International law is manifestly in a state of flux on this issue. For some, there is a "clear trend towards the acceptance of remedial secession". ${ }^{218}$ Yet it is disputed that any rule in this sense has fully crystallized. It comes therefore as no surprise that scholars are divided on the existence of remedial secession. ${ }^{219}$ The Independent International Fact-Finding Mission on the Conflict in Georgia rightly held that "a limited, conditional extraordinary allowance to secede as a last resort in extreme cases is debated in international legal scholarship. However, most authors opine that such a remedial 'right' or allowance does not form part of international law as it stands. The case of Kosovo has not changed the rules." 220 Thus, remedial secession remains for the time being "a fundamentally doctrinal ectoplasm, embellished with a few abstract positions States have taken with a cold mind". 221

In any case and for the sake of the argument, the right to remedial secession poses formidable legal challenges, including establishing the meaning of "people" as well as of identifying whom can legitimately claim to represent such "people"; defining and applying the criteria indispensable to set the threshold of violation of fundamental rights - in terms of gravity, extension and duration; and determining in which forms other States and International Organizations may assist the effective exercise of such entitlement. From this perspective, it may be questioned whether in the Kosovo crisis a permanent change of territorial status was indispensable almost ten years after the violent repression of 1999 was ended.

What is sure, it that if a right to remedial secession exists, it can be exercised only in extreme circumstances, as systematically and unambiguously indicated by the States supporting it. While taking a quite sympathetic stand, the Supreme Court of Canada emphasised that "[a] right to external self-determination (which in this case potentially takes the form of the assertion of a right to unilateral secession) arises in only the most extreme of cases and, even then, under carefully defined circumstances". 222

Even the most cursory analysis of the enjoyment of human rights, rule of law and democratic governance in Catalonia would demonstrate that the situation is not even remotely comparable with what is required to invoke remedial secession. To start with, the record of Spain regarding compliance with the European Convention on Human Rights denotes a rate of condemnations which is absolutely incompatible with the situation of massive and egregious violations of human rights that could trigger

216 Spain, Written Statement, 16 April 2009, p. 17.

217 China, Written Statement, 14 April 2009, p. 5, declared that in the exercise of the right to self-determination, "the territorial integrity of a sovereign State should be respected rather than undermined".

218 M. Weller, Escaping the Self-Determination Trap (Leiden: Nijhoff, 2008) 64.

219 Amongst the author arguing for the existence of the right to remedial secession, see, in particular, A. Buchanan, Justice, Legitimacy and Self-Determination (Oxford: OUP, 2004), Chapter 8; Raič, supra n. 106, Chapter 7; C. Tomuschat, Secession and Self-Determination, in Kohen (ed.), supra n. 66; Buchheit, supra n. 199; Weller, supra n. 218, 69. Contra, K. Del Mar, 'The Myth of Remedial Secession', in D. French (ed.), Statehood and Recognition (Cambridge: CUP, 2013) 79; S.F. van den Driest, Remedial Secession. A Right to External Self-Determination as a Remedy to Serious Injustices? (Antwerpen: Intersentia, 2013), Chapter 6.

${ }^{220}$ Report, vol II (September 2009) 141.

${ }^{221}$ R. Kolb, 'Autodétermination et "sécession-remède” en droit international public', Global Community (2013) 57, 76.

222 Quebec Case, supra n. 100, para 126. 
a plea of remedial secession. The argument is even more compelling considering the absence of any intra-State complaint filed against Spain. Further, violations on the scale required to justify remedial secession would certainly have led to the activation of the mechanism foreseen in Article 7 of the Treaty of the EU. There is no evidence that the application of Article 7 was ever envisaged in relation to the situation in Catalonia.

On a global level, respect by Spain of human rights under the numerous legal instruments it has ratified has been regularly monitored by the Human Rights Council and the other competent committees and bodies of the UN. Spain - as any other State of the organisation - has been found in breach of some of its international commitments on human rights. It is however impossible to detect any trace of the existence of a massive, egregious, and systematic violation of human rights, in Catalonia or elsewhere in the country. ${ }^{223}$ Finally, no State has formally of informally complained or protested with Spain for massive, egregious and systematic violation of human rights. Even if remedial secession is accepted as legal entitlement under international law to break away from the parent State, it seems incontrovertible that the human rights situation in Catalonia - and generally in Spain - is not even remotely approaching the threshold that may trigger it.

\section{(K) RIGHT TO DECIDE AND SELF-DETERMINATION}

As seen earlier (Section C), the claim to independence put forward by Catalonia revolves essentially around the right to self-determination and the right to decide, sometimes conflating the two. The right to decide, which is quite peculiar to the Catalan case, deserves to be examined separately.224

The "right to decide" intended as legal entitlement to choose the political status of a minority or territorial entity to the point of breaking away from the parent State is unknown in international law. It would amount to a surrogate of a general right to secession, which, as demonstrated above, cannot be upheld. The territorial integrity of States has consistently been treated by States as a sacrosanct principle. Even in the context of colonial, alien or foreign domination, the holder of the right to external self-determination is the population of the territorial unit subject to such domination. Internal self-determination, in turn, must be exercised within the jurisdiction of States.

By assimilating the right to decide to external self-determination, Catalonia's claim deliberately disregards the fundamental distinction between self-determination within and outside the colonial context. Like internal self-determination, any right to decide must be construed by putting together the relevant human rights protected under treaty and customary international law within the jurisdiction of each State. These rights include typically the right to freedom of expression, freedom of assembly, freedom of association, the right to free and democratic elections, and the right to take part to the conduct of public affairs. It is worth noting that these rights continuously evolve and may be subject to restrictions when necessary to protect public interests.

It can also be recalled that the right to decide is not expressly provided for in Spanish law. As pointed out by the Constitutional Court, however, it expresses "a political aspiration that may be

${ }^{223}$ For an overview, see UN Human Rights Council, Spain, First and Second Universal Periodic Review, respectively 2010 and 2015, text here.

${ }^{224}$ See N. Levrat, S. Antunes, G. Tusseau, P. Williams, Catalonia's Legitimate Right to Decide. Paths to SelfDetermination (2017), text here; D. Turp, N. Caspersen, M. Qvortrup, Y. Welp, The Catalan Independence referendum: An assessment of the process of self-determination (2017), esp. Ch. 7, text here. 
upheld in the constitutional order" 225 and is built up - as it was done in resolution 5/X - by several legal principles protected under the Constitution, namely the principles of democratic legitimacy, pluralism and legality. What was crucial, for the Court, was that the right to decide must be exercised within the constitutional framework.

In a scholarly report published in 2017, the right to decide has been defined as reflecting "the liberal democratic principle that people have the right to democratic self-expression by popular vote. It does not refer to any purported right to external self-determination". ${ }^{226}$ The report divides the process toward independence in three phases. The initial phase leads to the holding of a referendum and the declaration of independence. The final phase (or better the outcome) is "the requirement of statehood" or more precisely "what is required for a State to be considered as independent and legitimate". International law, the argument goes, is "well developed" regarding both phases. The second phase refers to everything that happens between the initial and final phases and is believed to be less developed in international law.

The study however examines only the first phase of the process and concludes that both State practice and international decisions show that international law does not prohibit "a sub-state entity from deciding its political destiny by assessing the will of its people" or a declaration of independence. ${ }^{227}$ The conclusion is correct, but simply applies the ICJ findings in the Kosovo advisory opinion. Beyond that, the report does not substantiate any right to unilateral secession under international law. It simply provides an overview of recent declarations of independence and observes that in several cases they have been followed by the establishment of effective and independent governments, sometimes recognized by the member States of the EU. This is of no assistance for the purpose of demonstrating the existence of a right to unilateral secession and its articulation in legal terms.

The foregoing brings us back to internal self-determination. The vagueness of the content of the right as well as of the corresponding obligations incumbent upon Spain make the assessment of any complaints made by the Catalan authority rather arduous. From the standpoint of international law, however, it seems difficult to argue that Catalonia's current level of self-government does not adequately satisfy its right to internal self-determination. There seems to be little doubt that the people of Catalonia enjoy the right to freedom of expression, speech, and association, as well as the right to take part in periodic and free elections at both local and central level. Furthermore, Spain's legal order undoubtedly offers Autonomous Communities a particularly high level of decentralisation. ${ }^{228}$ Both in law and fact, Catalonian authorities seem able to fully protect and promote their linguistic and cultural identity, most prominently in education. They seem capable to effectively decide without any undue interference by the central government on all matters falling within the scope of Article 148 of the Constitution. This allows Catalonia to freely develop and pursue its political and economic agenda within the limits of the Constitution.

The crux of the matter remains the tension that may arise when the enjoyment of internal selfdetermination by a people or a territorial entity is perceived as inadequate and may become confrontational and even lead to an attempt to break away from the State. The central State is not

225 Supra n. 13, Ground 4.

${ }^{226}$ Levrat et al, supra n. 224. For no apparent reason, the definition is relegated in footnote n. 106 of the report.

227 At 79.

228 See E. Casanas Adam, 'The Constitutional Court of Spain: From System Balancer to Polarizing Centralist', in N.T. Aroney, J. Kincaid (eds.), Courts in Federal Countries: Federalists or Unitarists (Toronto: UTP, 2017 ), $367,370$. 
only entitled to choose the constitutional order it prefers but has also a duty to defend it when it is challenged by a territorial entity. Defending the constitutional order is of paramount importance for the protection of the rights and interests of the whole population of the country as well as those of other provinces. The measures adopted to defend the constitutional order, however, must be consistent with the international commitments of the State.

From this perspective, it is worth recalling that Law 15/2015 on the Constitutional Court, which modified Organic Law 2/1979, enhanced the powers of the Court to ensure the enforcement of its own decisions. The legislation was not intended to apply specifically to autonomous communities, but to have general application (i.e. applicable also to central authorities). Law 15/2015 was considered by the Council of Europe Venice Commission. The Commission stressed that "[d]isregarding a judgment of a Constitutional Court is equivalent to disregarding the Constitution and the Constituent Power, which attributed the competence to ensure this supremacy to the Constitutional Court. When a public official refuses to execute a judgment of the Constitutional Court, he or she violates the principles the rule of law, the separation of powers and loyal cooperation of state organs". 229

In a document submitted to the Venice Commission, the Spanish Government declared that Law $15 / 2015$ only objective was "safeguarding the supremacy of the Constitution in a State governed by the rule of law". ${ }^{230}$ It also stressed that the measures envisaged in Law 15/2015, which could be applied at the national, regional and local level, must be proportionate and be lifted as soon as they achieve their objective, namely compliance with the Court decision. ${ }^{231}$ It finally emphasised that analogous provisions can be found in the Constitutions of several European countries, including Germany, Austria and Switzerland.

On 5 October 2017, the Constitutional Court provisionally suspended, on the basis of Law 15/2015, the plenary sitting of the Parliament of Catalonia scheduled on 9 October 2017. It must be recalled that meanwhile, the Catalonia Parliament declared itself not "subject to the decisions of the institutions of the Spanish State, in particular the Constitutional Court". ${ }^{232}$

The Constitutional Court's decision was subsequently scrutinized by the European Court of Human Rights (ECtHR) from the standpoint inter alia of Article 11 (freedom of assembly and association) and Article 3 Protocol I (right to free elections). ${ }^{233}$ In an unanimous decision declaring the application inadmissible, the ECtHR went through the conditions imposed by Article 11 to restrict freedom of assembly, namely that they are prescribed by law, pursue a legitimate aim and are necessary in a democratic society. It identified the legal basis for the Constitutional Court's decision in Article 56 of the Organic Law on the Constitutional Court, which expressly provides for the adoption on exceptional circumstances of preventive and provisional measures. It further held that the suspension of the plenary session of the Catalan Parliament was predictable, since such session was convened on the basis of Law 19/2917, which had itself been suspended by the Constitutional Court. Regarding the aim of the contested measure, the Court shared the position taken by the

229 Opinion 827/2015, 13 March 2017, 14.

${ }^{230}$ Position of Spain, Executive Summary and Report, 29 September 2016, CDL-REF(2016)034, 7.

${ }^{231}$ Ibidem.

${ }^{232}$ Resolution 1/XI, supra n. 16, para 6.

${ }^{233}$ Forcadell I Lluis et al. v. Espagne, Requête 75147, Décision, 28 May 2019. See M. Miranda López, A. García de Enterría Ramos, 'La suspensión del pleno del Parlamento de Cataluña ante el Tribunal Europeo de Derechos Humanos Comentario a la Decisión de la Sección Tercera del Tribunal Europeo de Derechos Humanos, de 7 de mayo de 2019', 107 Revista Cortes Generales (2019) 21. 
Constitutional Court in the decision rendered on 5 October that the suspension was intended to pursue a legitimate aim, namely the protection of the rights and freedom of the members of the Catalan Parliament belonging to the minority. Finally, the Court assessed the necessity of the measure restricting the freedom of assembly. In this respect, it held that the interference with the right to assembly was reasonable, even considering the reduced margin of appreciation enjoyed by State, as it addressed an "imperative social need".

As far as the right to free elections was concerned, the Court did not categorically rule out that a referendum could fall within the scope of Article 3, Protocol 1, provided that the free expression of the opinion of people in the choice of legislature is guaranteed. For the Court, this was not the case of the Catalan referendum as the session of the Parliament was convened in accordance with Law 19/2017, which had been adopted by the Catalan Parliament but suspended by the Constitutional Court.

\section{(L) DECLARATION OF INDEPENDENCE}

The question of whether international law prohibits an entity within a State to issue a declaration of independence was central in the Kosovo advisory opinion. ${ }^{234}$ The Court held that "the practice of States does not point to the emergence in international law of a new rule prohibiting the making of a declaration of independence". ${ }^{235}$ It also rejected the argument made by several States that "a prohibition of unilateral declarations of independence is implicit in the principle of territorial integrity as it held that the scope of the principle of territorial integrity is confined to the sphere of relations between States". ${ }^{236}$ It further clarified that when unilateral declarations of independence were treated as illegal, this was not due to their unilateral character, "but from the fact that they were, or would have been, connected with the unlawful use of force or other egregious violations of norms of general international law, in particular those of a peremptory character (jus cogens)". ${ }^{237}$ This occurred, for instance, with regard to the unilateral declaration of independence made by a racist minority in Southern Rhodesia. It was not the unilateral character of the declaration or its objective that triggers the illegality of the declaration and the obligation not to recognize, but rather the violation of the norm on the right to self-determination. In other words, the racist regime was not the holder of the right to self-determination or had the competence to exercise it. ${ }^{238}$

The indifference of international law towards the declaration of independence is a corollary of the indifference toward secession itself. Thus, under international law the right to decide cannot be invoked to legally support a claim of independence from the general government. A declaration of independence is not in itself inconsistent with any rules of international law, as clearly upheld by the ICJ in the Kosovo advisory opinion. As a result, the declaration of independence issued by Catalonia does not imply as such any breach of international law.

${ }^{234}$ Supra n. 80.

235 Para 79.

236 Para 80.

237 Para 81.

${ }^{238}$ Raič, supra $\mathrm{n} .106,134$. See also V. Gowlland-Debbas, Collective Responses to Illegal Acts in International Law. UN Action in the Question of Southern Rhodesia (Leiden: Brill, 1990). 


\section{(M) WAY AHEAD}

The preceding sections have focused on the independence claim put forward by the authorities of Catalonia and demonstrated that from the standpoint of international law no legal entitlement to break away from Spain can be substantiated; and further that in fact no independence has been obtained by Catalonia at to this date. The still unresolved question of Catalonia must thus be tackled from a different perspective, namely the distribution of powers between the central government and Catalonia. While the internal organization of a State is in principle a matter for domestic law, the distribution of powers between the central government and its territorial unities has important implications for the international relations of the State.

It is worth noting that in July 2019 the Government of Catalonia adopted Strategic Plan for Foreign Action and European Union Relations 2019-2022. ${ }^{239}$ Reminiscent of the Plan adopted in 2014, but limited to the relations with the EU, the Strategic Plan designs the role Catalonia intends to play on the international arena as "a country recognised around the world". The Spanish Government immediately challenged the Plan as inconsistent not only with the Spanish Constitution, ${ }^{240}$ and its Article 149 in particular, but also with Law 2/2014 on the External Relations of Spain, ${ }^{241}$ and Law 25/2014 on International Treaties concluded by Spain. ${ }^{242}$ On 30 October 2019, the Constitutional Court suspended the Plan in accordance with Article 161.2 of the Spanish Constitution. ${ }^{243}$ The suspension was further extended on 23 June 2020 in order avoid creating the appearance that Catalonia is a subject of international law which may cause irreparable damages to Spanish foreign policy should the Plan eventually be declared unconstitutional. ${ }^{244}$

The decision will certainly confirm the position consistently maintained by the Constitutional Court throughout the crisis as reiterated in Decision 28/2016, ${ }^{245}$ which offers a comprehensive and systematic treatment on the roles and prerogatives of the central government and Catalonia, as well as on the external relations of Catalonia.

The Court first insisted that Spain is a composite State (Estado compuesto) and that its territorial entities with political autonomy are not subjects of international law and cannot therefore participate in international relations. It follows that the central government has the exclusive competence it the field of international relations, as clearly provided for in Article 149.1.3 of the Constitution and reflected in the principle of unity of action abroad, which is enshrined in Law 2/2014 on External Relations. The Court further clarified that the exclusive competence of the central government refers to the relations between international subjects and most prominently the conclusion of treaties (ius contrahendi), the external representation of the State (ius legationis), as well as to the creation of international obligations and the international responsibility of the State.

Despite the lack of international legal personality, an Autonomous Community is allowed to carry out its activities outside its territory and even outside the territorial limits of Spain, provided that such external projection is necessary or convenient for the exercise of its own powers and does not invade

${ }^{239}$ Government of Catalonia, Ministry for Foreign Action, Institutional Relations and Transparency, text here.

${ }^{240}$ Gobierno de España, Requerimiento de incompetencia al Gobierno de la Generalitat de Cataluña en relación con el Acuerdo GOV/90/2019, de 25 de junio.

241 Law 2/2014, 25 March 2014.

242 Law 25/2014, 27 November 2014.

243 Text here.

${ }^{244}$ Constitutional Court, Informative Note N. 62/2020, 23 June 2020.

245 Decision 28/2016, 22 December 2016. 
the exclusive competence of the State in matters of international relations. In other words, nothing prevents an Autonomous Community from presenting itself as an actor playing a role at the international level, if this occurs within the constitutional and statutory framework. To ensure the unity and coherence of Spain external relations and to avoid or remedy possible damages to the direction and implementation of foreign policy, the central government is competent to establish appropriate measures to regulate and coordinate the activities of the Autonomous Communities with an external projection.

The decision deals in detail with the question of the competence to conclude international treaties. The Court confirmed its settled jurisprudence that the Spanish Constitution clearly provides for the exclusive competence of the State, being the only subject of international law, to conclude international treaties (ius contrahendi). The finding is nonetheless without prejudice to the exercise by Autonomous Communities of certain activities related to the process of drafting treaties (such as advocating their conclusion or contributing to design its content), as long as they do not undermine the State's powers to negotiate, conclude and if appropriate ratify them. The Court also admitted that the Autonomous Communities are entitled to conclude "collaboration agreements", as envisaged in Catalonia Law 16/2014, on condition that these agreements fall within the scope of the Autonomous Communities' powers and promote their interests.

Regarding consular and diplomatic relations, the Court reiterated that Article 149.1.3 of the Constitution confers the exclusive competence on the State in matters of international relations, including consular and diplomatic relations (ius legationis). Autonomous Communities, being deprived of international legal personality, are prevented from establishing permanent representative bodies to subjects with international status. Yet, this is without prejudice to the establishment by Autonomous Communities of autonomous offices to the EU for the promotion and protection of their interests related to the exercise of their powers and provided that the competence of the State in matters of foreign relations is fully respected.

By resolving the conflict of competences between the central government and Catalonia, or more generally Autonomous Communities, the Court has defined the current legal framework within which a political solution of the Catalan crisis has to be achieved and drew a clear line separating the exclusive competences of Spain as subject of international law and the activities through which Catalonia can project itself internationally.

Under the current legal framework, a solution of the Catalan question may be within the reach of the parties, provided they are committed to negotiate in good faith. Two essential conditions must then be satisfied. On the one hand, Catalan authorities must formally renounce to any project affecting the unity and territorial integrity of Spain. Nothing in international law would prevent the Spanish government from agreeing on the secession of Catalonia, provided that adequate guarantees including a referendum - are put in place. Such a course of action, which would require an amendment of the Spanish Constitution, seems extremely unlikely. Catalan authorities must therefore respect the exclusive competences of the central government, especially with regard to international agreements and delegations abroad. On the other hand, the Spanish government must ensure that Catalonia fully enjoys its right to self-determination in its internal dimension, including the right to project its related activities outside the borders of Spain in accordance with the relevant constitutional and statutory provisions.

From the standpoint of international law, the parties benefit from the broadest freedom and can agree on whatever arrangements that may be mutually satisfactory and lead to full compliance of all 
international obligations of Spain. With regard to the conclusion of treaties, furthermore, "[n]o hard and fast rule defines the competence of less that fully sovereign States: everything depends on the special case". ${ }^{246}$ What is crucial is the commitment of the parties and their willingness to recognise each other rights, interests and ambitions. After having traced the way ahead, the Constitutional Court can guarantee that the entire process is fully consistent with the current legal framework.

Finally, negotiations remain essentially a domestic matter. The assistance of third parties presumably in the form of mediation, good offices, or conciliation - is allowed only with the consent of the central government. Absent such a consent, third parties would be liable of interfering within the internal affairs of the country. In the case of the Catalonian crisis, the Spanish government did not seek or consent to any external mediation, and the EU correctly declined to play any active role beyond encouraging the parties to engage in negotiations. ${ }^{247}$

\section{(N) CONCLUSIONS}

The article has examined from the standpoint of international law the long-lasting and still unresolved showdown between the Catalan authority and the central government, with the Spanish Constitutional Court playing a crucial role. The first element that emerges is that the documents and legal instruments adopted by the Catalan authorities contain vague and often inaccurate references to international law. Those authorities have frequently referred to the right to self-determination of people in a crescendo that led to bold claims to independence. The events leading to the referendum have been rather idiosyncratic and asynchronous due to the lack of any effective and independent Catalan government.

The article has demonstrated that Catalonia has no unilateral right to break away from Spain. The right of peoples to self-determination can be invoked only in the fight against colonial, alien, or foreign regime, or perhaps in the case of massive and systematic violations of human rights. Catalonia clearly does not fall in any of these categories. While the declaration of independence did not amount in itself to a breach of international law, the recognition of Catalonia would have been extremely premature.

A political solution to the showdown between Catalonia and the central government, in line with the decisions rendered by the Constitutional Court, is overdue and in the interest of both parties. The possibility of a consensual separation appears rather remote. Any solution must therefore be respectful of the territorial integrity and constitutional order of Spain and at the same time ensure that Catalonia fully enjoys its autonomy under the current Statute of Autonomy. All this can be done only in negotiations pursued with the right spirit. Time is the great master of life. Its eminent role in such intricate contexts as Catalonia's claims to independence is even more evident. Tempus regit actum, it is.

246 Jennings, Watts (eds.), supra n. 94, 1217.

247 Caplan, Vermeer, supra n. 37. 